\title{
Gauging the Impact of Payment System Innovations on Financial Intermediation: Novel Empirical Evidence from Indonesia
}

\begin{abstract}
In this paper, the relationship between innovations in the payment systems and financial intermediation is explored. By focusing on excess reserves and currency demand we provide evidence on the extant transmission mechanism. In this direction, a Generalised Method of Moments (GMM) and Vector Error Correction Model (VECM) techniques are applied to a dataset collated for Indonesia. We find that the financial intermediation is affected by currency demand whilst we observe a limited role of excess reserves in affecting financial intermediation. Credit card payments are found to have a statistically significant effect on currency demand, whereas debit card payments only influence the financial intermediation in the long-run. In addition, the Real Time Gross Settlement (RTGS) exerts an upward pressure on excess reserves. The findings are of great importance as they provide support to policies that favour payment migration to an electronic platform, particularly that of card-based payment systems.
\end{abstract}

Keywords payment systems, financial intermediation, excess reserves, currency demand, monetary policy

JEL Classifications E42, E58, N25, G21

\section{Introduction}

The definition of a payment system has been identified as facilitating a settlement between economic agents to complete their transactions. Payment systems serve as the plumbing to the economy (Kahn and Roberds, 2009). Their production is subject to economies of scale due to the significant investment in infrastructure needed to start the operation (large fixed costs) and the relatively small marginal cost of services provided using the existing infrastructure (Hasan et al., 2013). A massive improvement in technology with the introduction of the credit card, debit card, automatic teller machines (ATM) and the recent introduction of the Internet has reshaped how people pay.

The development of the payment system itself is seen by the authorities as an opportunity to overcome the income inequality by providing the payment infrastructure to remote places, particularly in the emerging market countries (Martowardojo, 2015). However, as mentioned previously, the cost of these services and more importantly a perception that these payment services may not be sufficiently profitable for the business.

Furthermore, these rapid innovations attract the attention of the monetary authorities to address the payment system in the monetary policy decision-making process. The increasing speed, reliability, and financial risks of the payment system may affect the money demand and money supply (Johnson, 1998). These developments provide a challenge to the effectiveness of the monetary instruments and the transmission mechanism which may centre on the financial intermediation. 
Innovations in the large value payment systems enhance excess reserves of the banking system as well as provide liquidity to the lending side. Furthermore, improvements in the retail payment systems can reduce the use of cash in transactions which enables banks to utilise the deposit side to the lending side. Given the validity of these premises, a set of research questions regarding the impact of payment systems innovation can be formulated in the following manner: First, how does improvement in payment systems affect currency holdings?, and secondly, what is the impact of customer limitation in the large value payment system on the relationship between the innovation of the payment system and loan supply?

Despite its relative importance and recent developments in the field of payment markets, the empirical literature on payments is rather sparse (Kahn and Roberds, 2009). In answering these questions, we empirically investigate the underlying relationships by collating data for Indonesia. Being the biggest economy in South-East Asia, Indonesia needs to take steps towards improving the involvement of the financial sector in the economy. Compared to other countries, Indonesia is relatively new to payment system innovations. The Automatic Teller Machine (ATM) card was firstly introduced in 1995 and Real Time Gross Settlement (RTGS) was launched in 2000. As recorded by the World Bank in the World Development Index, only $35.9 \%$ of the total population above 15 years old in the country had bank accounts in 2014 , increased from only $19.6 \%$ in $2011^{1}$. In addition, the loan to GDP, which suffered at the lowest value after the 1997-1998 Asian Crisis at $17.34 \%$ in Q1-2000, increases to $34.75 \%$ in $\mathrm{Q} 2-2017^{2}$.

A novel element of this paper is that that for the first time we consider policies embodied in the payment system such as the limitation of the value that can be settled through the large value payment systems. It would have been interesting to incorporate the Internet banking data or other forms of telecommunication-based money such as 'Applepay', 'Googlepay' or 'GoPay' (Indonesia) to complement the analysis but due to the lack of availability of such data, only card-based transactions such as ATM/debit and credit cards were used. In this context, it can be argued that telecommunication-based money can be representative of a bank's deposit accounts since these services usually require a bank account or a debit card.

This paper makes three contributions. Firstly, it provides empirical evidence on how improvements in payment systems affects financial intermediation through excess reserves and currency holding; secondly, it gauges the impact of limitations in the amount of transaction value in payment systems as means of reducing uncertainty over the payment flows as well as bank's excess reserves; and thirdly, we demonstrate that a reduced currency holding may increase the loan supply whilst the increasing use of payment technology, such as debit cards and credit cards, contributes to the decreasing currency holding. 
The remainder of the paper is organised as follows: Section 2 highlights the literature that has discussed the role of payment systems in financial intermediation whilst section 3 presents a simple model that is used to examine the role of the payment system in financial intermediation. Section 4 touches on the empirical estimation as well as discusses generated evidence and finally section 5 provides some concluding remarks.

\section{The Role of Payment Systems in Financial Intermediation}

A payment is a transfer of monetary value which intends to free any liabilities that occur in exchanging goods and services (Kahn and Roberds, 2009). In a market economy, economic agents are independent to choose any forms of payment to settle a transaction. A payment system comprises the instruments, organisations, operating procedures, and information and communication systems used to initiate and transmit payment information from payer to payee and to settle payments (Bank for International Settlement, 2001). This payment system ensures the circulation of money, therefore, central banks as authorities in the issuing of money, are always interested in the smooth running of payment systems.

The payment system can be categorised into two types in terms of their end-customers; the wholesale payment systems and the retail payment systems (Kahn and Roberds, 2009). Wholesale payment systems deal with the intermediary institutions such as banks and/or other financial institutions in the form of a large-value payment system (LVPS). There are two types of LVPS based on their settlement process; i) gross settlement which is settled simultaneously in real time by using a platform called RTGS, and ii) the clearing system which operates on the net settlement basis where the settlement is performed after netting all the incoming and outgoing payments at the end of the day. Second is the retail payment system which serves the end customers such as households and firms. This retail payment system contains many forms of payment instruments including card-based systems such as ATM and debit and credit cards and digital payment such as Internet banking.

The role of the central bank depends on each mandate in the law of the relevant country ${ }^{3}$. This can range from issuing banknotes and currency, providing the settlement operations, the management of collateral and domestic currency reserves accounts.

The importance of the payment system to the economy has been documented by Hasan et al. (2013) who argue that innovation in the retail payment system helps to stimulate the overall economy and growth. This proposition is derived from their test of various retail payment instruments which include card payments and cheques. They find that card payments have the largest impact on the economy.

Merrouche and Nier (2009) argue that improvement in payment systems technology encourages the use of banking deposits (inside money) as a payment medium for customers and thus influences the proportion between 
holding cash (outside money) and holding deposits (inside money). Furthermore, a well-functioning interbank market will be built to provide end-of-day funds. Therefore, this decreases the urgency of banks to maintain a large amount of excess reserves (outside money).

Banks play a major role in providing both financial intermediation and payment services. Hasan et al. (2012) point out that innovations in retail payment systems have a positive impact on the bank's performance through both fee-based income and interest income. The efficiency of payment systems may affect all banks' in their ability to provide financial services to customers. It may, in turn, affect the ability of the banks to accumulate liquidity. By doing so, interest rates which are being paid by the bank to the customers may be affected (Merrouche and Nier, 2012). However, vast amounts of literature in banking and monetary policies rule out the interplay between these two activities. These studies, such as Fuerst (1992), focus on the role of the supply of money (outside money) from the central bank to the banking sector to ensure the financial intermediation.

The banking industry is dealing with the nature of liquidity mismatch. On the one hand, banks cannot easily liquidate their lending before maturity. On the other hand, they face liquidity shocks from the deposit withdrawals. An influential study from Diamond and Dybvig (1983) presents a discussion of the role of the banking system in creating liquidity by taking in short-term deposits and producing long-term investments.

However, the role of outside money is not being taken into account in this framework. The disturbance is only identified in the behaviour of the deposits in the banking system (inside money). The framework of how the conversion from inside money to outside money may influence the supply of loan is given by (Bernanke and Blinder, 1988). In a monetary contraction environment, banks will find that their deposits are deteriorating; hence the banks will also face decreasing reserves. With given reserve requirements, banks may also decrease their loan supply. If the loan supply decreases and banks are the main sources of financing then this will affect economic activity.

In the same vein, Diamond and Rajan (2006) highlight that a pressure in deposits withdrawal with a shift into the currency without any increase in money supply from the central bank will diminish the credit supply. By ensuring that the claim of deposit withdrawal is inside the banking system, the bank can continue to ensure the supply of loan to the economy without facing a liquidity shock. When banks deal with a liquidity shock, they are generating a disintermediation effect by reducing their activities in the system. Moreover, they shift their portfolio of investments towards more liquid and less productive assets (Ennis and Keister, 2003).

By providing payment services to the customer in the large value settlement system, such as the RTGS, a bank can decrease its balance in the central bank reserves by investing in cash and liquidity management. With 
continuous and individual payment instructions, banks need to have sophisticated liquidity management. Banks depend on two sources in fulfilling their payment obligations: reserve balances and/or loan from the central bank and incoming funds acquired from other banks during the day (Galbiati and Soramäki, 2011). Using the reserve balance or taking loans from the central bank involves a cost which prompts economic incentives. Relying on incoming funds may not have a cost, yet it is beyond the bank's control. Therefore, it is very important to have sophisticated liquidity management in place. The more involvement a bank has in the payment system, the more investment in liquidity management pay-offs. This requires an active participation in the money market - by both borrowing and lending - to determine the balance in the central banks; therefore, it enhances the money market liquidity.

Nguyen and Boateng (2013) find that increasing excess reserves in China is a signal that banks are preparing for the increased risk which, in turn, reduces their loan supply. A contraction of the deposit division of the bank can be seen as an increased risk to reduce the loan supply. An uncertainty in payment flows in the large value payment system influences the transmission of the monetary policy by increasing the pressure for interbank market rates and the banks' reserves balance in the central bank for a precautionary reason (Kamhi, 2006). Another interesting result is also reported by studies that employed the U.S. data. Güntner (2015) points out that the excess reserves level in the U.S. data is not related to the loan supply. The level of excess reserves only crowds out the money market. The pivotal role of the money market to facilitate the continuation of payment flows and the level of excess reserves and lending to the economy became evident in the 2007-2009 financial crises.

On the retail payment systems level, Wang and Wolman (2016) take the U.S. data from various locations in the country. They impose a nominal threshold whereby customers may use debit cards above that threshold and use cash below that threshold. They conclude that the use of debit cards reduces the demand for cash. This result is also supported by David et al. (2016) who use French data. They highlight the fact that the debit card provides two services for consumers - cash withdrawal and payment - that have contrasting effects on cash holdings and cash usage. They find that payment services through the card exceed the use of the ATM for cash withdrawals and have a negative impact on the currency demand. The same conclusion is also drawn by Lippi and Secchi (2009) by estimating from the Italian market.

Turning to the investigation on credit card holding and the household demands for currency, Duca and Whitesell (1991) argue that credit card ownership affects a lower demand for currency and demand deposits with no effect on small time deposits. However, Yang and King (2011) have a different view regarding the ability of credit cards to reduce currency demand. The presence of ATMs, online banking and electronic funds transfer 
reduce the cost of having to visit banks. Therefore, the credit card holding may not have an impact on the currency demand in aggregate.

\section{Conceptual Framework and Data}

\subsection{Loan Supply, Reserves and Deposits}

In order to gauge a comprehensive impact of payment system innovation on financial intermediation, we need to consider the role of bank deposit as a medium of payment. The framework proposed in the seminal work of Diamond and Dybvig (1983) is rather constrained in that it offers only an analysis of how credit creation is affected by the deposit withdrawal from the banking system and switched into the currency. Given the current innovation of the payment system, however, a payment can be performed by an economic agent not only through withdrawal from a bank deposit that was converted in the form of currency demand but also through using the bank deposit directly via the large value payment system, the retail payment system or both.

More recently, Rockoff (1993) and Merrouche and Nier (2009) offer a framework that takes into account both currency demand and bank deposit. Both of these approaches consider the impact of deposit withdrawal through currency conversion and through payment system on credit creation by linking the level of reserves that a bank needs to maintain in line with the loan supply. Thereby, any withdrawal in the bank deposit, either through conversion to currency or in the form of payment system services will affect the reserves of a bank.

In view of the above, in this study, we follow Rockoff (1993) and Merrouche and Nier (2009) which provide the basis on which we develop the conceptual framework of analysis in order to gauge the impact of payment system on credit. Unlike other approaches that focus on inside money to evaluate the credit creation, the two aforementioned approaches that constitute the building block in our research effort, are effectively utilised to explore the relationship between the efficiency of payment system services and financial intermediation by incorporating both the role of inside money and outside money.

This paper assumes that economic agents want to maintain a fraction of their nominal income in the form of liquid assets. These assets are represented by two assets, Deposit (D) and Cash (C) according to a constant elasticity of substitution production function. Hence, a modified quantity theory can be presented as:

$$
\left[(\delta D)^{-\alpha}+C^{-\alpha}\right]^{-\frac{1}{\alpha}}=k Y
$$

where $\delta$ is an index of the quality of deposits that affect payments and $\mathrm{Y}$ is the nominal income and $\sigma=1 /((1+\alpha))$ is the elasticity of substitution. This paper assumes that economic agents try to maximise utility from holding 
monetary assets by setting the marginal product of deposits, the currency deposits ratio C/D may be expressed as a linear function of the quality deposits $\delta$.

These two types of assets are lent out in two different channels. Currency is being lent directly without any financial intermediation and deposits are intermediated by the banking system. Previous literature such as Bernanke and Blinder (1988) is followed which assumes that loan cannot be perfectly substituted by bonds. This paper views that this assumption is practical in the context of the emerging market conditions, particularly Indonesia. The local bond market needs to be developed. As monitored by the Asia Development Bank, the corporate bond market in Indonesia is only $2.56 \%$ of total GDP ${ }^{4}$.

A representative bank's balance sheet is:

$$
R+L_{s}=D
$$

where $\mathrm{R}$ is the total bank's reserves, $\mathrm{L}_{-} \mathrm{s}$ is the supply of loans and $\mathrm{D}$ is the level of bank deposits. The bank is required to retain their reserves in the central bank in proportion to its deposit base based on certain reserve requirements, therefore total reserves $\mathrm{R}$ include required reserves and excess reserves ER so let $\rho$ represent the reserve requirement rate thus:

$$
E R=R-\rho D
$$

Following the aforementioned discussion, the bank maintains excess reserves to prepare for the customer payments flows which may create a liquidity risk to the bank. The bank would require borrowing from the central bank at a high penalty rate to cover the payment obligations. This liquidity management can be performed in the interbank market to optimise the cost. Therefore, the interbank market becomes more liquid.

This study combined the equations (2) and (3) to get the loan supply function:

$$
L_{s}=(1-\rho) D-E R
$$

The introduction of smooth and efficient payment systems can be considered as a permanent positive shock to $\rho$ and D and a permanent negative shock to the banks' desired level of excess reserves ER. Furthermore, there is a positive feedback mechanism that is associated with a higher equilibrium output and loan, if the output is a function of the available supply of credit. Another channel of payment systems which affects credit in this framework is the reserves channel subject to the central bank not accommodating the commercial bank's demand or in the absence of massive quantitative easing policies. 


\subsection{Empirical methodology}

Following the preceding conceptual framework, the first step of this paper's approach is to assess whether the presence of innovation in large-value payment systems, such as RTGS and the Clearing System, reduces excess reserves. Specifically, as explained previously, this paper uses a modified demand equation for excess reserves developed by Agénor et al. (2004). We, therefore, purport to examine the level of excess reserves demand in the banking sector by capturing the impact of payment flows directly. It should also be emphasized that our approach takes into account the liquidity shock and macroeconomic condition to capture the dynamics of these factors to affect the excess reserves.

Other approaches such as Beaupain and Durré (2013) focuses on the price level of the interbank market to capture shocks to the reserves. According to Warjiyo (2014), however, this approach may not represent the interbank condition encountered in Indonesia i.e. shallow and concentration in several banks. In this sense, the interbank price level may represent the price premium that one bank charges another. Therefore, an empirical framework of analysis that is based on solely price information may not be adequate to provide a comprehensive answer to our research questions. Potentially, alternative approaches, such as the one by Güntner (2015) who employs the Dynamic Stochastic General Equilibrium (DSGE) model to assess the excess reserves, could have also been used. It should be stressed however, that this approach may not incorporate the payment flows and the payment system regulations that restrict the value of customer transactions in the large value payment systems that we want to investigate.

Our empirical approach is expressed as follows:

$$
\begin{aligned}
\operatorname{ERDEP}_{t}=a_{0}+ & a_{1} \operatorname{ERDEP}_{t-1}+a_{2} \text { DEVPS }_{t}+a_{3} R_{t}+a_{4} \text { IBRATE }_{t}+a_{5} Y / Y T R E N D_{t} \\
& +a_{6} \text { PSREG }_{t}+a_{7} \text { DHOLIDAY }_{t}+\varepsilon_{t}
\end{aligned}
$$

where $E R D E P_{t}$ is the ratio of excess reserves $E R$ over total bank deposit, $D$ at time $t$; in line with previous studies by Merrouche and Nier, 2009, 2012; and Nguyen and Boateng, 2013, both Rupiah (local currency) and foreign exchange deposits are included in this study. $D E V P S_{t}$ is the large value payment system (LVPS) transaction value at time $t$ minus its 12 -month moving average. This variable, purports to capture the payment shocks to the bank. We also employ the total value of the LVPS to capture the overall performance of the liquidity management of the bank. A negative sign in the coefficient suggests that banks have already performed liquidity management and reduced the excess reserves; $R R_{t}$ is the reserve requirement ratio that proxies the effect of the changes in the reserve requirement to the excess reserves; $I B R A T E_{t}$ is the interest rate in the interbank market that capture the penalty rate if the bank needs to cover the liquidity when there is a shock in the payment flows; Y/YTREND is the 
deviation of output from the trend which represents the output shocks in the economy. As pointed out by Agénor et al. (2004), shocks in output will have a positive impact on the excess reserves. Due to unavailability of monthly data for output, the retail sales index is used as a proxy of output since this index is reported to have a correlation

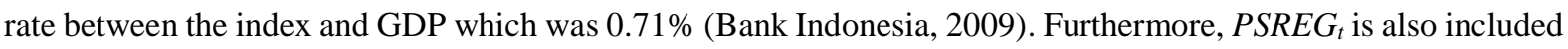
which is the dummy of payment system regulations that restrict the value of customer transactions in the large value payment systems; both in RTGS and clearing. There are several instances when the central bank sets a limit for a customer to do a transaction in RTGS and Clearing in Indonesia ${ }^{5}$. A negative sign is expected in this variable which means that limiting the value of individual transactions in both LVPS will help to minimise the payment shock to banks. Also incorporated is the seasonal factor in Indonesia in DHOLIDAY to capture the cyclical factor because of the seasonal holiday of Eid al-Fitr which is a big celebration in Indonesia as suggested by Bank Indonesia (2017) and $\varepsilon_{t}$ is the error term.

Secondly, we investigate the extent to which innovation in the retail payments, such as debit cards and credit cards, affect the currency holding in the economy by constructing a currency demand equation in the following manner:

$$
\begin{aligned}
& \text { CURSAV }_{t}=b_{0}+ b_{1} \text { VOLCARD }_{t}+b_{2} Y_{t}+b_{3} I N F_{t}+b_{4} \text { CARDPOP }_{t}+b_{5} \text { INFRA }_{t}+b_{6} \text { DEPO } M_{t} \\
&+b_{7} \text { DHOLIDAY } \\
&+\varepsilon_{t}
\end{aligned}
$$

where CURSAVtis the ratio of the total currency in circulation outside of the banking system divided by the saving and demand deposits in the banking system at time $t$; VOLCARD $D_{t}$ is the number of card transactions which is derived from the number of transactions of each debit card or credit card divided by the number of debit or credit cards in the economy. Rinaldi (2001) highlights that the number of card transactions could better represent the use of cards. However, this paper divides it by the number of cards to take into the account the introduction of new cards to the economy. The sign of this variable is expected to be negative to capture the substitution effect of card payment instruments and the transaction of the payment instruments. $Y_{t}$ is the retail sales index which is used as a proxy of output and $I N F_{t}$ is the Customer Price Index (CPI) inflation; DEPO1Mt is the nominal 1-month time deposit interest rate in the banking system; CARDPOP $t$ is the number of debit and credit cards per 1000 population which is expected to bear as in the case of VOLCARD , a negative sign; INFRAt is the total number of ATM and Electronic Fund Transfer Point-of-Sales (EFTPOS) terminals.

The final step will be to assess the extent to which financial intermediation is related to reductions in excess reserves and currency holding by setting up the following specification: 


$$
\begin{gathered}
\text { LOANGROWTH }_{t}=c_{0} \text { LOANGROWTH }_{t-1}+c_{1} \text { Channel }_{t}+c_{2} Y G_{t}+c_{3} \text { INF }_{t}+c_{4} \text { BIRATE }_{t} \\
+c_{5} R_{t}+c_{6} \text { XRATE }_{t}+\varepsilon_{t}
\end{gathered}
$$

where LOANGROWTHt is the financial intermediation which is represented by the year-on-year growth of loan in the banking system; Channelt is the ratio of excess reserves over the total deposit or the ratio of currency in circulation over total savings and demand deposits in the banking system. This variable is expected to bear a negative sign hence, indicating the impact of payment system innovations on financial intermediation. $Y G_{t}$ is the year-to-year growth rate of the retail sales index whereas BIRATE is the central bank's policy rate. It is interesting to see the impact of capital flow to the financial intermediation as represented by XRATE. Following other studies such as Korinek and Sandri (2016), the capital inflows will exert an upward pressure on the exchange rate whilst capital outflows will cause the exchange rate to depreciate.

To test this relationship empirically, especially when estimating the link between financial development and economic development, several economic problems may occur such as problems in regressor endogeneity as well as the possibility of autocorrelation (Hasan et al., 2013). Any endogeneity issues will be identified by the Durbin-Wu-Test test in which case adopting a GMM approach as suggested by Hasan et al. (2013) and Nguyen and Boateng (2013) will rectify any problems or in the absence of endogeneity then the OLS model is used as suggested by Bound et al. $(1993,1995)$ as OLS provides a better estimation when the excluded instruments are only weakly correlated with the endogenous variables.

\subsection{Data}

The Bank of Indonesia was the main provider for the monthly dataset of the payment system statistics for RTGS, clearing and card payment transactions volume and value. In particular, the RTGS - which dominates the wholesale payment system - consists of $96.73 \%$ and the debit card consists of the $95.57 \%$ of the total transactions value respectively as recorded in June 2017. Titiheruw and Atje (2009) provide an excellent survey of the payment systems in Indonesia. In addition, data for excess reserves is taken from Monetary and Payment System Selected Indicators whilst the retail sales index is obtained from the retail sales survey from Bank Indonesia. All other data are taken from Indonesia financial statistics. The sample covers the period from January 2005 to June 2017 (150 observations). The exchange rate is measured as USD/IDR and taken from Bank Indonesia with the average of 1 USD equals IDR 10,507 over the sample period. This implies that a negative sign means an appreciation of the domestic currency (IDR) and a positive sign means a depreciation of the IDR. Figure 1 plots the selected time series used in this paper. 

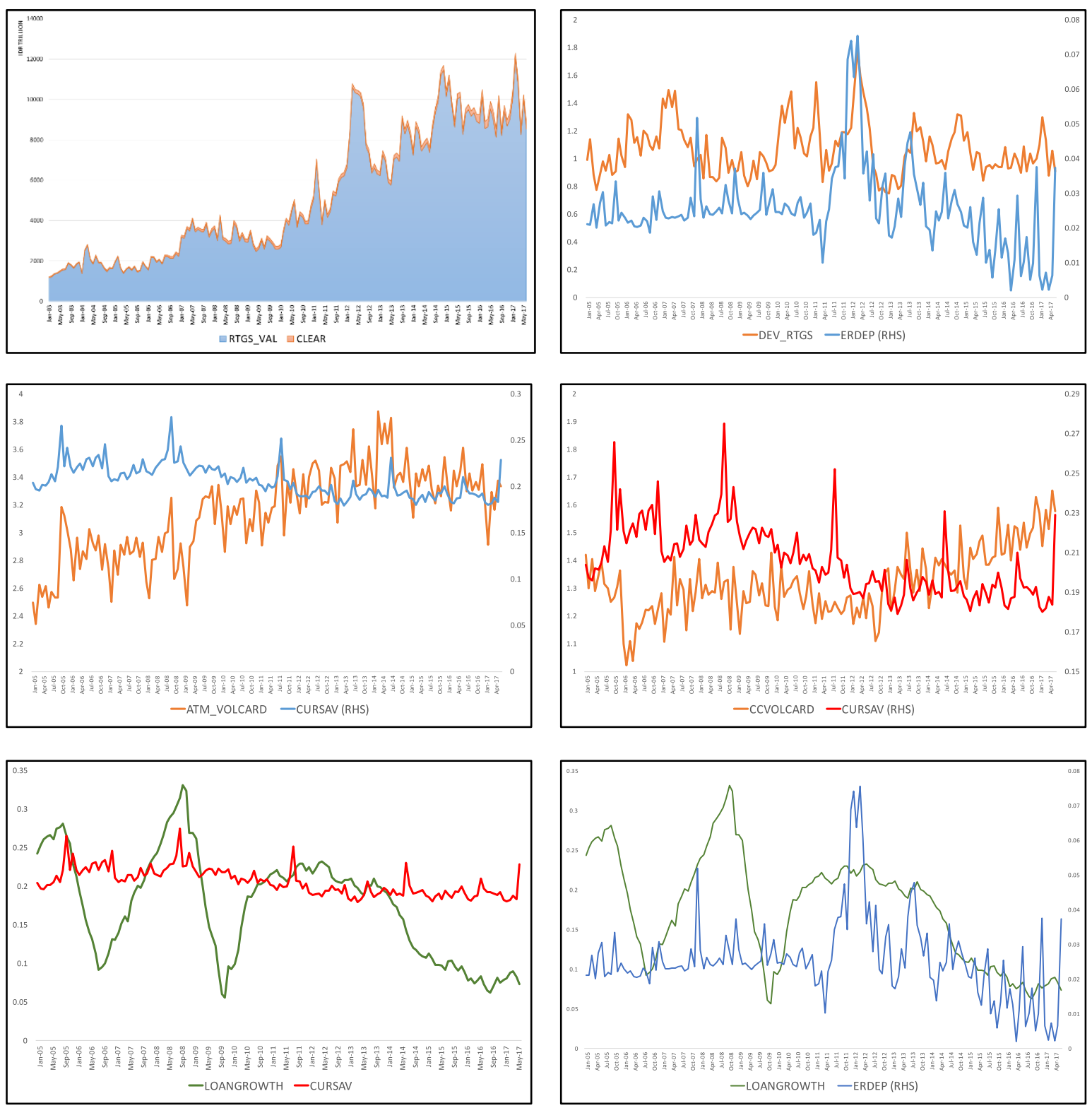

\section{Estimation Results and Discussion}

\subsection{Payment system innovations and excess reserves}

Following section 3.2, we start our investigation by using both RTGS and clearing turnover separately in order to see the impact of each LVPS on the excess ratio. The Durbin-Wu-Test test indicates a presence of endogeneity and therefore a GMM methodology is adopted to provide the estimates reported in Table 1. 
Table 1 Estimation Result for Dependent Variable ERDEP

\begin{tabular}{|c|c|c|}
\hline \multirow[b]{2}{*}{ Independent Variable } & \multicolumn{2}{|l|}{ Dependent Variable: } \\
\hline & ERDEP & ERDEP \\
\hline C & $\begin{array}{l}-0.010856 \\
(0.009982)\end{array}$ & $\begin{array}{c}0.004693 \\
(0.015343)\end{array}$ \\
\hline DEV_RTGS & $\begin{array}{c}0.011335 * * \\
(0.004681)\end{array}$ & \\
\hline DEV_CLEAR & & $\begin{array}{l}-0.009118 \\
(0.009544)\end{array}$ \\
\hline $\mathrm{RR}$ & $\begin{array}{c}0.125351 * * \\
(0.054077)\end{array}$ & $\begin{array}{c}0.057081 \\
(0.060770)\end{array}$ \\
\hline IBRATE & $\begin{array}{l}-0.000318^{*} \\
(0.000173)\end{array}$ & $\begin{array}{l}-0.000206 \\
(0.000214)\end{array}$ \\
\hline YSHOCK & $\begin{array}{c}0.008329 \\
(0.005136)\end{array}$ & $\begin{array}{c}0.010482 \\
(0.007651)\end{array}$ \\
\hline ERDEP(-1) & $\begin{array}{c}0.382659 * * * \\
(0.120671)\end{array}$ & $\begin{array}{c}0.576900 * * * \\
(0.110606)\end{array}$ \\
\hline RTGSREG_01 & $\begin{array}{c}-0.009361 * * * \\
(0.002438)\end{array}$ & \\
\hline RTGSREG_02 & $\begin{array}{c}-0.006460 * * \\
(0.002502)\end{array}$ & \\
\hline CLEARREG_01 & & $\begin{array}{c}0.002087 \\
(0.003657)\end{array}$ \\
\hline CLEARREG_02 & & $\begin{array}{l}-0.000658 \\
(0.003641)\end{array}$ \\
\hline H_DUMMY & $\begin{array}{c}0.005953 * * * \\
(0.001470)\end{array}$ & $\begin{array}{c}0.005979 * * * \\
(0.001547)\end{array}$ \\
\hline $\mathrm{R}^{2}$ & 0.55 & 0.51 \\
\hline DW Stat & 1.64 & 1.86 \\
\hline J-Statistics & 9.95 & 8.89 \\
\hline No. of observation & 149 & 149 \\
\hline Instrument specification: & $\begin{array}{c}\text { DEV_RTGS(-1) DEV_RTGS(-2) } \\
\text { RR IBRATE YSHOCK ERDEP(- } \\
\text { 1) ERDEP(-2) RTGSREG_O2 } \\
\text { RTGSREG_03 H_DUMMY }\end{array}$ & $\begin{array}{l}\text { DEV_CLEAR(-1) DEV_CLEAR(- } \\
\text { 2) RR IBRATE YSHOCK ERDEP(- } \\
\text { 1) ERDEP(-2) CLEARREG_O1 } \\
\text { CLEARREG_O2 H_DUMMY }\end{array}$ \\
\hline
\end{tabular}

Note: Robust standard errors in parentheses. ${ }^{* * *}, * *, *$ denote statistical significance at $1 \%, 5 \%$ and $10 \%$

respectively.

The yielded evidence suggests that payment shocks on RTGS (DEV_RTGS) has a positive and significant impact on excess reserves which is in line with Kamhi (2006). Hence, implying that payment flows may exert an upward pressures on excess reserves but stands at stark contrast to Merrouche and Nier (2009) who find that payment innovations significantly reduce the excess reserves ratio in a sample of Eastern Europe countries.

One factor that may contribute to why payment shocks cause an upward pressure in excess reserves is the shallowness of the interbank market in Indonesia (Warjiyo, 2014). The interbank money market has limited transactions and the liquidity is concentrated in certain banks (Bank Indonesia, 2017b). Thus, the ability of banks 
to access different source of funding may compel them to set up sophisticated liquidity management. The banking system may depend only on the central bank to access funding which causes reluctance in using such a facility because of the 'failure bank' stigma. Therefore, payment shocks that can happen anytime during the day due to the characteristic of the RTGS that requires a real-time settlement may drive the banks to accumulate reserves.

A limited ability of the interbank market to provide the liquidity makes the interbank market rates prone to a shock. A small demand in the market may cause the rate jumps. Therefore, we find that the interbank rate (IBRATE) has a negative and significant impact on excess reserves as expected. Banks are lending their reserves to the interbank market when the interest rate raises and holding their reserves when the interest rate falls. We also find that the reserve requirement (RR) appears to have a significant positive result as expected. RTGS regulations to limit the amount of transaction value in payment systems (RTGSREG_01 and RTGSREG_02) show negative and significant coefficients as expected. This result indicates that regulations restrain the transaction value alleviate the impact of the payment shocks on excess reserves as expected.

\subsection{The Effect of Card Usage to the Currency Holdings}

In an attempt to gain an insight into the relationship between payment systems and financial intermediation we extend our analysis with the retail payment systems. A similar approach to the previous section was adopted and the impact of debit/ATM cards (DEB_VOLCARD) and credit cards (CCVOLCARD) was tested to the currency (CURSAV) separately to examine their individual impacts. This approach intends to clarify the debate within the literature regarding the role of each card-based payment system.

We conduct an ADF test to check the stationarity of the variables the results of which are reported in Table 2.

Table 2 ADF Test result

\begin{tabular}{|c|c|c|c|}
\hline VARIABLES & $\mathbf{I}(\mathbf{0})$ & $\mathbf{I}(\mathbf{1})$ & $\mathbf{I}(2)$ \\
\hline CURSAV & ** & & \\
\hline CCVOLCARD & & $* * *$ & \\
\hline CCCARDPOP & $*$ & & \\
\hline DEB_VOLCARD & & $* * *$ & \\
\hline DEBCARDPOP & & $* * *$ & \\
\hline$\overline{\mathrm{INFRA}}$ & & $*$ & \\
\hline
\end{tabular}

Note: ***, **, * denote statistical significance at $1 \%, 5 \%$ and $10 \%$ respectively.

An inspection of the respective ADF tests indicate the presence of unit root in credit card transaction volume over the number of credit cards (CCVOLCARD), debit card transaction volume over the number of debit cards (DEB_VOLCARD), the number of credit cards over population (CCCARDPOP), and the number of debit 
cards over population (DEBCARDPOP). Following the standard methodological process when dealing with nonstationary variables we proceed to check for cointegration by utilising a Johansen approach. The results of the Johansen test, provided in Tables 3 and 4, both unrestricted co-integration rank tests (trace and max eigenvalue statistics), indicate that the null of no co-integration was rejected at the $5 \%$ level of significance.

Table 3 Johansen Test Result for CURSAV, DEBVOLCARD, Y, INF, DEPOIM, ATMCARDPOP and INFRA

\begin{tabular}{|c|c|c|c|c|}
\hline Hypothesized No. of CE(s) & Eigenvalue & Trace Statistic & 0.05 Critical Value & Prob.*** \\
\hline $\begin{array}{l}\text { Unrestricted Cointegration } \\
\text { Rank Test (Trace) }\end{array}$ & & & & \\
\hline None * & 0.307382 & 179.4971 & 125.6154 & 0 \\
\hline At most $1 *$ & 0.250084 & 125.8746 & 95.75366 & 0.0001 \\
\hline At most $2 *$ & 0.223115 & 83.85679 & 69.81889 & 0.0025 \\
\hline At most 3 & 0.147883 & 46.99728 & 47.85613 & 0.0601 \\
\hline $\begin{array}{l}\text { Unrestricted Cointegration } \\
\text { Rank Test (Maximum } \\
\text { Eigenvalue) }\end{array}$ & & & & \\
\hline None * & 0.307382 & 53.62247 & 46.23142 & 0.0069 \\
\hline At most $1 *$ & 0.250084 & 42.01786 & 40.07757 & 0.0299 \\
\hline At most $2 *$ & 0.223115 & 36.85951 & 33.87687 & 0.0214 \\
\hline At most 3 & 0.147883 & 23.36452 & 27.58434 & 0.1584 \\
\hline
\end{tabular}

* denotes rejection of the hypothesis at the 0.05 level by trace and max eigenvalue, **MacKinnon et al. (1999) pvalues

Table 4 Johansen Test Result for CURSAV, CCVOLCARD, Y, INF, DEPOIM, CCCARDPOP and INFRA

\begin{tabular}{|l|c|c|c|c|}
\hline \multicolumn{1}{|c|}{ Hypothesized No. of CE(s) } & Eigenvalue & Trace Statistic & 0.05 Critical Value & Prob.** \\
\hline Unrestricted Cointegration & & & & \\
Rank Test (Trace) & 0.360157 & 206.14 & 125.6154 & 0.0000 \\
None * & 0.321835 & 142.2859 & 95.75366 & 0.0000 \\
At most $1 *$ & 0.260705 & 86.74985 & 69.81889 & 0.0013 \\
At most 2* & 0.131105 & 43.5556 & 47.85613 & 0.1196 \\
At most 3 & & & & \\
Unrestricted Cointegration & & & & \\
Rank Test (Maximum & & & 46.23142 & 0.0003 \\
Eigenvalue) & 0.360157 & 63.85405 & 40.07757 & 0.0004 \\
\hline None * & 0.321835 & 55.53606 & 33.87687 & 0.0029 \\
At most 1* & 0.260705 & 43.19425 & 27.58434 & 0.3345 \\
At most 2* & 0.131105 & 20.09622 & & \\
At most 3 & & & & \\
\hline
\end{tabular}

$*$ denotes rejection of the hypothesis at the 0.05 level by trace and max eigen value, **MacKinnon et al. (1999) p-values

Having established the existence of cointegrating relationships, the VECM is used to examine the impact of the payment system innovation on the currency demand. To determine the number of lags, a range of standard criteria is used (see Appendix D).

An impulse response function analysis is carried out by using the Cholesky decomposition of the matrix of covariance. In this approach, the order of the variables is important because a shock in the previous variables 
has a contemporaneous effect on both the variable itself and on the ones that follow (Enders, 2004). Following Rinaldi (2001), it is assumed that money is immediately affected by the other variables but it does not have a contemporaneous effect on any of them. The graphical representation of the impulse response function is presented in Appendix E.

The short run as well as the long run estimates are provided in Tables 5 and 6.

Table 5 Short-run Dynamics for the impact of debit/ATM cards on the currency demand

\begin{tabular}{|c|c|c|c|}
\hline Variables & Coefficient & Std. Error & t statistics \\
\hline $\mathrm{ECM}_{\mathrm{t}-1}$ & -0.250523 & 0.116005 & $-2.159586^{* *}$ \\
\hline$\Delta$ CURSAV $_{\mathrm{t}-1}$ & -0.516013 & 0.175477 & $-2.940639 * * *$ \\
\hline$\Delta$ CURSAV $_{\mathrm{t}-2}$ & -0.38522 & 0.188229 & $-2.046549 * *$ \\
\hline$\Delta$ CURSAV $_{\mathrm{t}-3}$ & -0.128986 & 0.17558 & -0.734627 \\
\hline$\triangle$ CURSAV $_{\mathrm{t}-4}$ & 0.067105 & 0.129766 & 0.517125 \\
\hline$\Delta \mathrm{DEB}_{-} \mathrm{VOLCARD}_{\mathrm{t}-1}$ & -0.000683 & 0.02665 & -0.025627 \\
\hline$\Delta \mathrm{DEB}_{-} \mathrm{VOLCARD}_{\mathrm{t}-2}$ & -0.012327 & 0.034528 & -0.357023 \\
\hline$\Delta \mathrm{DEB}_{-}$VOLCARD $\mathrm{t}_{\mathrm{t}-3}$ & -0.022703 & 0.032314 & -0.70258 \\
\hline$\Delta \mathrm{DEB}_{-} \mathrm{VOLCARD}_{\mathrm{t}-4}$ & -0.009563 & 0.025121 & -0.380674 \\
\hline$\Delta \mathrm{Y}_{\mathrm{t}-1}$ & 0.010701 & 0.019539 & 0.547687 \\
\hline$\Delta \mathrm{Y}_{\mathrm{t}-2}$ & 0.037045 & 0.020039 & $1.848679 *$ \\
\hline$\Delta \mathrm{Y}_{\mathrm{t}-3}$ & 0.016867 & 0.019044 & 0.885642 \\
\hline$\Delta \mathrm{Y}_{\mathrm{t}-4}$ & -0.009222 & 0.018076 & -0.510182 \\
\hline$\Delta \mathrm{INF}_{\mathrm{t}-1}$ & -0.133375 & 0.157203 & -0.848428 \\
\hline$\Delta \mathrm{INF}_{\mathrm{t}-2}$ & -0.096249 & 0.146322 & -0.657784 \\
\hline$\Delta \mathrm{INF}_{\mathrm{t}-3}$ & -0.072775 & 0.141127 & -0.515669 \\
\hline$\Delta \mathrm{INF}_{\mathrm{t}-4}$ & -0.180271 & 0.129726 & -1.389633 \\
\hline$\Delta$ DEPO1M $\mathrm{M}_{\mathrm{t}-1}$ & 0.015771 & 0.004898 & $3.219544 * * *$ \\
\hline$\Delta \mathrm{DEPO} 1 \mathrm{M}_{\mathrm{t}-2}$ & -0.004783 & 0.006078 & -0.786821 \\
\hline$\Delta \mathrm{DEPO} 1 \mathrm{M}_{\mathrm{t}-3}$ & 0.002638 & 0.006262 & 0.421209 \\
\hline$\Delta \mathrm{DEPO}_{\mathrm{M}} \mathrm{M}_{\mathrm{t}-4}$ & -0.003583 & 0.005084 & -0.70486 \\
\hline$\triangle \mathrm{DEBCARDPOP}_{\mathrm{t}-1}$ & 0.080807 & 0.060752 & 1.330122 \\
\hline$\triangle$ DEBCARDPOP $_{\mathrm{t}-2}$ & -0.090052 & 0.06739 & -1.336284 \\
\hline$\triangle \mathrm{DEBCARDPOP}_{\mathrm{t}-3}$ & 0.045914 & 0.061455 & 0.747116 \\
\hline$\triangle$ DEBCARDPOP $_{\mathrm{t}-4}$ & -0.039089 & 0.059046 & -0.662018 \\
\hline$\Delta \mathrm{INFRA}_{\mathrm{t}-1}$ & -0.006104 & 0.003391 & $-1.80002 *$ \\
\hline$\Delta$ INFRA $_{t-2}$ & -0.00295 & 0.003564 & -0.827668 \\
\hline$\Delta$ INFRA $_{\mathrm{t}-3}$ & -0.005725 & 0.003639 & -1.573137 \\
\hline$\Delta \mathrm{INFRA}_{\mathrm{t}-4}$ & -0.002079 & 0.003495 & -0.594812 \\
\hline H_DUMMY & 0.012083 & 0.002632 & 4.589937 \\
\hline $\mathrm{R}^{2}$ & \multicolumn{3}{|c|}{0.52} \\
\hline S.E. of regression & \multicolumn{3}{|c|}{0.010503} \\
\hline F-statistic & \multicolumn{3}{|c|}{$4.242907(0)$} \\
\hline
\end{tabular}

Note: $* * *, * *, *$ denote statistical significance at $1 \%, 5 \%$ and $10 \%$ respectively. 
Table 6 Long-run estimation results for the impact of debit/ATM cards on the currency demand

\begin{tabular}{|l|r|r|r|}
\hline CURSAV & \multicolumn{1}{c|}{ Coefficient } & \multicolumn{1}{c|}{ Std. Error } & \multicolumn{1}{c|}{ statistics } \\
\hline DEB_VOLCARD $_{\mathrm{t}-1}$ & -0.084108 & -0.03802 & $-2.21199 * *$ \\
$\mathrm{Y}_{\mathrm{t}-1}$ & 0.13182 & -0.02574 & $5.12193 * * *$ \\
INF $_{\mathrm{t}-1}$ & -0.058972 & -0.04235 & -1.39250 \\
DEPO1M $_{\mathrm{t}-1}$ & 0.001036 & -0.0016 & 0.64893 \\
DEBCARDPOP $_{\mathrm{t}-1}$ & -0.032897 & -0.02854 & -1.15279 \\
INFRA $_{\mathrm{t}-1}$ & -0.002671 & -0.00169 & -1.57618 \\
$\mathrm{C}$ & -0.288833 & -0.10735 & $-2.69060^{* * *}$ \\
\hline
\end{tabular}

Note: $* * *, * *, *$ denote statistical significance at $1 \%, 5 \%$ and $10 \%$ respectively.

An inspection of the results presented in Table 5 suggests that in the short-run, the volume of debit card transaction over the number of debit cards (DEB_VOLCARD) is not significant, hence, implying that the use of debit/ATM cards to withdraw money is not as important as using cash in daily transactions. Currency demand will not be affected if occasional customers are the majority users of the ATMs (Stix, 2003). In contrast, if the ATMs are used by regular customers then the impact of the volume of debit card transactions will have a negative and significant relationship with the aggregate currency demand. In line with this finding, the number of debit cards per 1000 people (DEBCARDPOP) appears to have a positive and significant impact, suggesting that in the short-run, debit cards are predominantly used to withdraw currency. However, the card-based payment infrastructure (INFRA) has a negative and significant coefficient which implies that the availability of the infrastructure may reduce the demand for currency. The unbalanced number of terminals across the country may contribute to this slightly puzzling result (Snellman and Viren, 2009). Overall, the number of terminals reduces the aggregate currency demand, however, the use of the cards and terminals in withdrawing large amount of money may cause the conflicting result.

Retail sales (Y) bears a positive coefficient which confirms that many transactions in the economy still use cash as highlighted by Titiheruw and Atje (2009). Therefore, this puts an upward pressure on currency when there is a positive shock in the retail sales. Nominal interest rate (DEPO1M) has a positive and significant effect on currency demand (CURSAV) which is in line with Lippi and Secchi (2009). The positive coefficient of nominal interest rate confirms that technology drives the ambiguity relationship of money and interest rates. Another factor which may be attributed to this relationship of money and interest rates is the heterogeneity of the customers who use debit cards. Customers in rural or remote areas may withdraw a large amount of money to avoid the transaction costs of more frequent visits to the ATMs since the availability of the machine is limited and most transactions are still cash-based. As for the error correction term (ECM), it indicates that about $29 \%$ of the disequilibrium is corrected on a monthly basis. 
Although a statistically significant relationship is not observed between the volume of debit card transactions (DEB_VOLCARD) and currency demand in the short-run (CURSAV), a negative and statistically significant relationship is found between these two variables in the long-run as indicated in Table 6. The preceding discussion about the short-run impact of the debit/ATM card to the currency demand provides the underlying reason why this phenomenon occurs. As pointed out by Stix (2003), regular customers may utilise the use of debit cards to substitute cash by exploiting the feature of the card through the machine such as transfer or payment. This verifies that ATMs are utilised by regular customers in the long-run.

This argument is also supported by the card-based payment infrastructure (INFRA) which bears a negative coefficient in the long-run hence suggesting that the availability of infrastructure may reduce the demand for currency. Furthermore, the variable reflecting the number of debit cards per 1000 people (DEBCARDPOP) is also consistent with the previous argument. The results obtained in the long-run also confirms the dominance of cash in the economy which can be observed through the positive coefficient in retail sales (Y).

On the basis of the preceding exposition it has transpired that currency demand and debit cards are inversely related. Next we explore the relationship between the credit card and the currency demand. The results are reported in Tables 7 and 8 . 
Table 7 Short-run Dynamics for the impact of credit cards on the currency demand

\begin{tabular}{|c|c|c|c|}
\hline Variables & Coefficient & Std. Error & t statistics \\
\hline $\mathrm{Ecm}_{\mathrm{t}-1}$ & -0.709561 & 0.151386 & $-4.687101 * * *$ \\
\hline$\Delta$ CURSAV $_{\mathrm{t}-1}$ & -0.113333 & 0.168928 & -0.670898 \\
\hline$\Delta$ CURSAV $_{\mathrm{t}-2}$ & -0.068298 & 0.175192 & -0.389849 \\
\hline$\Delta$ CURSAV $_{\mathrm{t}-3}$ & 0.108619 & 0.174124 & 0.623806 \\
\hline$\Delta$ CURSAV $_{\mathrm{t}-4}$ & 0.435473 & 0.171428 & $2.540262 * *$ \\
\hline$\Delta$ CURSAV $_{\mathrm{t}-5}$ & 0.318441 & 0.160298 & $1.986558 * *$ \\
\hline$\Delta$ CURSAV $_{\mathrm{t}-6}$ & 0.271074 & 0.125589 & $2.158426 * *$ \\
\hline$\Delta$ CCVOLCARD $_{\mathrm{t}-1}$ & -0.027413 & 0.02026 & -1.353088 \\
\hline$\Delta \mathrm{CCVOLCARD}_{\mathrm{t}-2}$ & -0.038114 & 0.02669 & -1.428024 \\
\hline$\Delta$ CCVOLCARD $_{\mathrm{t}-3}$ & -0.048106 & 0.031089 & -1.547367 \\
\hline$\triangle \mathrm{CCVOLCARDt}-4$ & -0.040271 & 0.030677 & -1.31276 \\
\hline$\triangle \mathrm{CCVOLCARD}_{\mathrm{t}-5}$ & -0.040124 & 0.026334 & -1.52366 \\
\hline$\Delta$ CCVOLCARD $_{\mathrm{t}-6}$ & -0.022474 & 0.017886 & -1.256515 \\
\hline$\Delta \mathrm{Y}_{\mathrm{t}-1}$ & 0.03844 & 0.019039 & $2.019065 * *$ \\
\hline$\Delta \mathrm{Y}_{\mathrm{t}-2}$ & 0.06512 & 0.01842 & $3.535315 * * *$ \\
\hline$\Delta \mathrm{Y}_{\mathrm{t}-3}$ & 0.052832 & 0.02022 & $2.61281 * *$ \\
\hline$\Delta \mathrm{Y}_{\mathrm{t}-4}$ & -0.006267 & 0.020002 & -0.313302 \\
\hline$\Delta \mathrm{Y}_{\mathrm{t}-5}$ & 0.009728 & 0.0188 & 0.517439 \\
\hline$\Delta \mathrm{Y}_{\mathrm{t}-6}$ & -0.028587 & 0.018627 & -1.534661 \\
\hline$\Delta \mathrm{INF}_{\mathrm{t}-1}$ & 0.010053 & 0.148104 & 0.067877 \\
\hline$\Delta \mathrm{INF}_{\mathrm{t}-2}$ & 0.183119 & 0.139914 & 1.3088 \\
\hline$\Delta \mathrm{INF}_{\mathrm{t}-3}$ & 0.029926 & 0.140219 & 0.213421 \\
\hline$\Delta \mathrm{INF}_{\mathrm{t}-4}$ & 0.131875 & 0.17723 & 0.74409 \\
\hline$\Delta \mathrm{INF}_{\mathrm{t}-5}$ & -0.000812 & 0.156305 & -0.005194 \\
\hline$\Delta \mathrm{INF}_{\mathrm{t}-6}$ & 0.372353 & 0.176195 & $2.113302 * *$ \\
\hline$\Delta \mathrm{DEPO}_{1} \mathrm{M}_{\mathrm{t}-1}$ & 0.009027 & 0.004901 & $1.841838 *$ \\
\hline$\Delta \mathrm{DEPO} 1 \mathrm{M}_{\mathrm{t}-2}$ & -0.007305 & 0.005719 & -1.277438 \\
\hline$\Delta$ DEPO1Mt-3 & 0.007371 & 0.005772 & 1.27711 \\
\hline$\Delta \mathrm{DEPO} 1 \mathrm{M}_{\mathrm{t}-4}$ & -0.007458 & 0.005753 & -1.296271 \\
\hline$\Delta \mathrm{DEPO}_{1 \mathrm{M}_{\mathrm{t}-5}}$ & 0.005953 & 0.00591 & 1.007358 \\
\hline$\Delta \mathrm{DEPO} \mathrm{M}_{\mathrm{t}-6}$ & -0.003042 & 0.005373 & -0.5662 \\
\hline$\Delta \mathrm{CCCARDPOP}_{\mathrm{t}-1}$ & -0.202552 & 0.081772 & $-2.477038 * *$ \\
\hline$\Delta \mathrm{CCCARDPOP}_{\mathrm{t}-2}$ & 0.000603 & 0.075796 & 0.007961 \\
\hline$\triangle \mathrm{CCCARDPOP}_{\mathrm{t}-3}$ & -0.133471 & 0.079357 & $-1.681912 *$ \\
\hline$\Delta \mathrm{CCCARDPOP}_{\mathrm{t}-4}$ & -0.00777 & 0.059581 & -0.130413 \\
\hline$\Delta \mathrm{CCCARDPOP}_{\mathrm{t}-5}$ & 0.023237 & 0.051671 & 0.449714 \\
\hline$\Delta \mathrm{CCCARDPOP}_{\mathrm{t}-6}$ & 0.019426 & 0.050091 & 0.387824 \\
\hline$\Delta$ INFRA $_{t-1}$ & -0.012923 & 0.00451 & $-2.865446 * * *$ \\
\hline$\Delta \mathrm{INFRA}_{\mathrm{t}-2}$ & -0.006618 & 0.003951 & $-1.675054 * *$ \\
\hline$\Delta$ INFRA $_{t-3}$ & -0.005408 & 0.003831 & -1.411709 \\
\hline$\Delta$ INFRAt-4 $_{t}$ & -0.001835 & 0.003918 & -0.46822 \\
\hline$\Delta$ INFRAt-5 & 0.001227 & 0.003419 & 0.359039 \\
\hline$\Delta$ INFRAt-6 & 0.001021 & 0.003384 & 0.301821 \\
\hline H_DUMMY & 0.014076 & 0.002415 & $5.828989 * * *$ \\
\hline $\mathrm{R}^{2}$ & \multicolumn{3}{|c|}{0.66} \\
\hline S.E. of regression & \multicolumn{3}{|c|}{0.00946} \\
\hline F-statistic & & $4.488029(0)$ & \\
\hline
\end{tabular}

Note: $* * *, * *, *$ denote statistical significance at $1 \%, 5 \%$ and $10 \%$ respectively.

Table 8 Long-run estimation results for the impact of credit cards on the currency demand

\begin{tabular}{|l|c|c|c|}
\hline CURSAV & Coefficient & Std. Error & t statistics \\
\hline CCVOLCARD $_{\mathrm{t}-1}$ & -0.060407 & -0.03651 & $-1.65444 *$ \\
$\mathrm{Y}_{\mathrm{t}-1}$ & 0.082763 & -0.0165 & $5.01690^{* * *}$ \\
INF $_{\mathrm{t}-1}$ & 0.221712 & -0.10852 & $2.04299 * *$ \\
DEPO1M $_{\mathrm{t}-1}$ & 0.004047 & -0.00186 & $2.18070^{* *}$ \\
CCCARDPOP $_{\mathrm{t}-1}$ & -0.159764 & -0.06469 & $-2.46971^{* *}$ \\
INFRA $_{\mathrm{t}-1}$ & -0.009977 & -0.00421 & $-2.37119 * *$ \\
$\mathrm{C}$ & -0.959045 & -0.26911 & $-3.56380 * * *$ \\
\hline
\end{tabular}

Note: $* * *, * *, *$ denote statistical significance at $1 \%, 5 \%$ and $10 \%$ respectively. 
The results in Tables 7 and 8 reveal a clearer picture of how the card-based payment systems affect the currency demand. Table 7 indicates that the volume of credit card transactions over the number cards (CCVOLCARD) is statistically significant in reducing currency demand (CURSAV) in the short-run. This is supported by both the number of credit cards per 1000 people (CCCARDPOP) and the point that card-based payment infrastructure (INFRA) have negative and significant coefficients which suggest that the number of cards in circulation and the availability of the infrastructure may reduce the demand for currency.

Similar to the finding for debit cards, retail sales (Y) is positive hence validating the dominance of the use of cash in the economy over other retail payment instruments. The nominal interest rate (DEPO1M) also has a positive and significant relationship with the currency demand (CURSAV) in the short-run. In addition, inflation (INF) exhibits a positive relationship with currency demand in the short-run. A significant and negative cointegrating relationship is also observed i.e. a speedy adjustment of around $68 \%$.

In Table 8, the volume of credit card transactions (CCVOLCARD) is negatively related to currency demand (CURSAV) in the long-run. This is consistent with the previous findings, such as Duca and Whitesell (1991), and differs from the finding of Yang and King (2011). The main difference between Yang and King (2011) and this study is the distinctive economic and banking structures in this paper's sample. Yang and King (2011) take their samples from the US economy which has a strong cheque culture whereas this study's sample is a cashbased economy. The use of cheques has been widespread for some time in the US. Hence, it can be argued that a card based system is not directly related. However, in the case of Indonesia, the substituting effect of cash and card payments will be directly transmitted without any intermediaries such as cheques in the US.

The substituting effect of credit card and cash payment is also supported by the negative coefficient of the number of credit cards per 1000 people (CCCARDPOP) and the number of terminals that can be used (INFRA) in the long-run. An increase in credit card possession is associated with a decrease in currency demand in the long-run. Consistent with the short-run result, the nominal interest rate (DEPO1M) and inflation (INF) also put pressure on the currency demand with a positive and significant coefficient in the long-run.

The findings of this study regarding the credit card suggest that the card-based payment system has a negative impact on the currency demand. The analysis of impulse-response function and forecast error variance decomposition do not differ significantly from this proposition. A shock from debit cards has a negative impact on the currency. However, it will increase over time then increase to a level lower than the initial one (See Appendix F). Interestingly, the currency demand decreases reacting to the volume of credit card transactions and starts to increase in the fourth period before coming back to the initial level. 


\subsection{Financial Intermediation}

In gauging the impact of excess reserves and currency demand on financial intermediation we employ a GMM specification (see Table 9).

Table 9 The Impact of Excess Reserves and Currency Demand on Financial Intermediation.

\begin{tabular}{|c|c|c|}
\hline \multirow[b]{2}{*}{ Independent Variable } & \multicolumn{2}{|l|}{ Dependent Variable: } \\
\hline & LOANGROWTH & LOANGROWTH \\
\hline \multirow[t]{2}{*}{$\mathrm{C}$} & $0.305485 * * *$ & $0.189406^{* *}$ \\
\hline & $(0.082831)$ & $(0.077351)$ \\
\hline CURSAV & $-0.255181 * * *$ & \\
\hline & $(0.096705)$ & \\
\hline ERDEP & & 0.066699 \\
\hline & & $(0.124826)$ \\
\hline \multirow[t]{2}{*}{ YG } & $0.027836 * *$ & $0.0229 * *$ \\
\hline & $(0.011163)$ & $(0.010965)$ \\
\hline \multirow[t]{2}{*}{ INF } & 0.04273 & 0.080396 \\
\hline & $(0.074952)$ & $(0.075295)$ \\
\hline \multirow[t]{2}{*}{ BIRATE } & $-0.297388^{*}$ & $-0.464078 * * *$ \\
\hline & $(0.157337)$ & $(0.146732)$ \\
\hline \multirow[t]{2}{*}{ XRATE } & $-0.021097 * * *$ & -0.013177 \\
\hline & $(0.007847)$ & $(0.008009)$ \\
\hline \multirow[t]{2}{*}{ RR } & $-0.577625^{* * *}$ & $-0.533172 * * *$ \\
\hline & $(0.10717)$ & $(0.109832)$ \\
\hline \multirow[t]{2}{*}{ LOANGROWTH $_{\mathrm{t}-1}$} & $0.988249 * * *$ & $0.966476 * * *$ \\
\hline & $(0.022102)$ & $(0.022737)$ \\
\hline \multirow{4}{*}{$\begin{array}{l}\mathrm{R}^{2} \\
\text { DW Stat } \\
\text { J-Statistics } \\
\text { No. of observation }\end{array}$} & 0.97 & 0.97 \\
\hline & 1.4 & 1.4 \\
\hline & 65.13 & 75.54 \\
\hline & 146 & 146 \\
\hline \multirow{5}{*}{ Instrument specification: } & C CURSAV(-1TO-4) SALESG(0TO- & ERDEP(-1TO-4) SALESG(0TO-4) \\
\hline & 4) INF(0TO-4) BIRATE(0TO-4) & INF(0TO-4) BIRATE(0TO-4) \\
\hline & LOANGROWTH(-1TO-4) & LOANGROWTH(-1TO-4) \\
\hline & XRATE(0TO-4) RR(0TO-4) & XRATE(0TO-4) RR(0TO-4) \\
\hline & H_DUMMY & H_DUMMY \\
\hline
\end{tabular}

Note: $* * *, * *, *$ denote statistical significance at $1 \%, 5 \%$ and $10 \%$ respectively.

We find a statistical negative relationship between currency demand and financial intermediation which is in line with our prior expectations. Output growth (YG) is related in a positive way with loan growth. In addition, the exchange rate (XRATE) has a negative and significant effect on loan growth suggesting that an exchange rate appreciation leads to an increase in the loan growth. It can be argued that capital flows may be one of the factors that cause the exchange rate to fluctuate. A massive volatility of capital inflows, following the unconventional monetary policy in advanced countries for instance, leads to an appreciation for the currency because of a strong demand for domestic assets such as stocks and bonds. The capital inflows provide an abundant of the liquidity which encourage banks to push their lending (Unsal, 2013). In contrast, large exchange rate depreciation could be related to a deterioration in external funding conditions during a crisis that triggers the capital outflows (Chu, 
2015). A depreciation of the exchange rate cuts the value of collateral and decreases the loan growth (Korinek and Sandri, 2016). This result confirms that the credit supply may exhibit a strong pro-cyclicality to the business cycle as highlighted by many studies, such as Rousseau and Wachtel (2002). The observation discerned in this study also confirms the role of the policy instruments - the policy rates (BIRATE) and reserve requirements (RR) - from the central bank to restrict loan growth.

However, the findings fail to identify any impact of excess reserves (ER) on financial intermediation which is in line with the studies by Merrouche and Nier (2009, 2012). As highlighted in Bathaluddin et al. (2012), Indonesian banks prefer liquidating their placement in the central bank to hold a large amount of excess reserves. After the Asian Economic Crisis in 1997, due to the Bank Indonesia Liquidity Support (BLBI) and the recapitalisation program, excess liquidity compels the central bank to employ a borrowing operation instead of a lending operation. By using this type of operation, the banking industry chooses to place funds in the form of the Central Bank's instruments with the interest rate income compared to investing funds in the unremunerated reserves account. This appears to be commonplace in many economies around the world as banks are reported to place their excess reserves which are acquired during the unconventional monetary policy within the financial system, particularly in the form of government bonds, rather than grant loans (Kregel, 2009).

Furthermore, such a development appears to be amplified by the volatility of capital flows following the current global financial crisis. After the emergence of capital inflows, domestic banks have had to face fierce competition where they have to compete with the foreign funds. Domestic banks need to take on higher-risk forms of finance and be exposed to a liquidity risk when a payment shock occurs or default to the financing side (Korinek, 2010). Furthermore, these capital inflows are subject to a sudden reversal which may cause turbulence in the domestic financial market. As already mentioned in the previous section, the shallowness of the domestic financial market drives banks to maintain a certain amount of reserves with preference to liquidate their placement in the central bank. Indonesian banks prefer placements in the Central Bank monetary operations instruments in the short-term tenor in anticipating the volatility in the capital flows and the currency demand (Bank Indonesia, 2017b).

The overall results explain why the currency ratio plays a major role in credit supply. A shock in the currency ratio, such as a large number of deposit withdrawals and conversion into cash, can affect the credit supply immediately. As demonstrated previously, card-based payment systems may be significant in preventing a rapid contraction in the credit supply by reducing the demand for currency and placing liquidity within the banking system. 


\section{Concluding Remarks}

This study provides a comprehensive analysis of the importance and significance of payment systems to financial intermediation in Indonesia and demonstrates how regulations that limit the amount of customers' transactions value through payment systems affect this role. The paper evaluates this relationship through both large-value payment systems and retail payment system channels by using excess reserves and currency demand.

On the large-value payment systems channels, the generated evidence suggests that the RTGS exerts a positive pressure on excess reserves. However, regulations that limit the value of customers' transactions help to alleviate this pressure by reducing the payment volatility. The Clearing System is found to be relatively insignificant in affecting the financial intermediation, along with its limitation. It can be argued that the small proportion of this payment system compared to the RTGS may cause this insignificant result. In addition, the regulations to limit the value of transactions, which have been imposed since the introduction of the RTGS, also contribute to the result.

Following the findings in the large-value payment systems channels, this paper highlights the importance of card-based payment systems in reducing currency demand in the retail payment systems channel. Credit cards are observed to have a statistically significant impact on the reduction of the currency demand. Debit cards, however, influence adversely currency demand only in the short-run.

Finally, this study produces empirical evidence on how currency demand is inversely related to financial intermediation. The implication of these findings is of paramount importance in that it provides support to policies that promote payment migration to an electronic platform, particularly card-based payment systems, such as a 'less-cash society (GNNT)', which has been implemented by the central bank of Indonesia. In addition, innovations in the retail payment system may increase banking competition and create an increase in efficiency (Sokołowska, 2015). In so far as this study adopts a macro-based framework, its analysis is limited to aggregate behaviour. It would also be interesting to observe the customers' payments behaviour based on primary data and explore how different demographic factors may have an impact on the currency demand.

Another interesting finding relates to the impact of excess reserves on financial intermediation. Similar to the preceding studies, such as Merrouche and Nier (2009, 2012) and Bathaluddin et al. (2012), this finding contributes to the enrichment of the debate on the view that monetary policies may have an impact on the supply of credit through influencing the excess reserves as suggested by Bernanke and Blinder (1988). The presence of excess liquidity however, may distort this channel. In the presence of excess liquidity, banks may be less reactive to the tightening of monetary policy (Nguyen and Boateng, 2013). In passing, it should be mentioned that this 
study does not incorporate the dynamics in the interbank market whilst the role of capital flows is potentially attributed to amplifying the domestic business cycle.

These empirical findings allow market participants and policymakers to gain further insight into the payment system services and the credit supply, both in the large value payment systems and retail payment systems. Policymakers can utilise the regulation to limit the transaction value to prevent the liquidity shocks to the banking sector. However, one should be cautious with this limit because a regulation that sets a very high transaction limit may cause the customers convert their payment into currency (cash-basis) which may be another source of shock to the banking system. Furthermore, a massive campaign in using the credit card to substitute the currency demand can also be carefully examined because of the creditworthiness of the customers which is beyond the scope of this paper.

In addition, our empirical findings suggest the central bank needs to enhance its monetary operation framework to contain excess reserves, capital flows and integrate with the presence of the newly-developed macroprudential policies. However, this strategy needs to be aligned with the overall long-term objectives of the central bank such as the inflation target. Focusing on the short-term fluctuation of the capital flows may distort the inflation expectation in the market whereas ignoring the short-term volatility may have the implication for the long-term objective of the central bank. This is also another debate that will be interesting to explore in the future.

\section{Notes}

\footnotetext{
${ }^{1}$ data available online at http://databank.worldbank.org/data/reports.aspx? source=2\&country=IDN

${ }^{2}$ data from Indonesian Financial Statistics, Bank Indonesia

${ }^{3}$ Bank for International Settlement (BIS) provides a detailed survey of the payment systems in various countries in their website www.bis.org

${ }^{4}$ Data available online at https://asianbondsonline.adb.org, accessed on 18 Sep 2017

${ }^{5}$ Appendix $\mathrm{C}$ provides a detail of the regulations that have been imposed to limit the transaction value on the LVPS
} 


\section{References}

Agénor, P.R., Aizenman, J. and Hoffmaister, A.W. (2004), "The Credit Crunch in East Asia: What Can Bank Excess Liquid Assets Tell Us?”, Journal of International Money and Finance, Vol. 23 No. 1, pp. $27-49$.

Bank for International Settlement. (2001), Core Principles for Systemically Important Payment Systems.

Bank Indonesia. (2009), Retail Sales Survey, available at: http://www.bi.go.id/en/publikasi/survei/penjualaneceran/Pages/SPE_0909.aspx.

Bank Indonesia. (2017a), Press Releases, available at: http://www.bi.go.id/en/ruang-media/siaranpers/Pages/sp_196817.aspx.

Bank Indonesia. (2017b), 2016 Economic Report on Indonesia, available at: http://www.bi.go.id/en/publikasi/laporan-tahunan/perekonomian/Pages/LPI_2016.aspx.

Bathaluddin, M.B., Purwanto, N.M.A. and Wibowo, W.A. (2012), "The Impact of Excess Liquidity on Monetary Policy”, Bulletin of Monetary Economics and Banking, Vol. 14 No. 3, pp. 245-267.

Beaupain, R. and Durré, A. (2013), "Central Bank Reserves and Interbank Market Liquidity in the Euro Area”, Journal of Financial Intermediation, Vol. 22 No. 2, pp. 259-284.

Bernanke, B.S. and Blinder, A.S. (1988), “Credit, Money, and Aggregate Demand”, American Economic Review, Vol. 78 No. 2, pp. 435-439.

Bound, J., Jaeger, D.A. and Baker, R. (1993), "The Cure Can Be Worse Than the Disease: A Cautionary Tale Regarding Instrumental Variables", NBER Technical Paper Series, No. 137, available at: http://www.nber.org/papers/t0137.pdf.

Bound, J., Jaeger, D.A. and Baker, R.M. (1995), "Problems with Instrumental Variables Estimation when the Correlation between the Instruments and the Endogenous Explanatory Variable is Weak", Journal of the American Statistical Association, Taylor \& Francis, Vol. 90 No. 430, pp. 443-450.

Chu, S.-Y. (2015), "Funding liquidity constraints and the forward premium anomaly in a DSGE model", International Review of Economics \& Finance, Vol. 39, pp. 76-89.

David, B., Abel, F. and Patrick, W. (2016), "Debit Card and Demand for Cash", Journal of Banking and Finance, Elsevier B.V., Vol. 73, pp. 55-66.

Diamond, D.W. and Dybvig, P.H. (1983), "Bank Runs, Deposit Insurance, and Liquidity", Journal of Political Economy, University of Chicago Press, Vol. 91 No. 3, pp. 401-419.

Diamond, D.W. and Rajan, R.G. (2006), "Money in a Theory of Banking", The American Economic Review VO - 96, Vol. 90 No. 1, p. 30.

Duca, J. V. and Whitesell, W.C. (1991), "Credit Cards and Money Demand: A Cross Sectional Study", Federal Reserve Bank of Dallas Research Paper, No. 9112.

Ennis, H.M. and Keister, T. (2003), “Economic Growth, Liquidity, and Bank Runs”, Journal of Economic Theory, Vol. 109 No. 2, pp. 220-245.

Fuerst, T.S. (1992), "Liquidity, Loanable Funds, and Real Activity”, Journal of Monetary Economics, Vol. 29 No. 1, pp. 3-24.

Galbiati, M. and Soramäki, K. (2011), “An Agent-Based Model of Payment Systems”, Journal of Economic Dynamics and Control, Vol. 35 No. 6, pp. 859-875.

Güntner, J.H.F. (2015), “The Federal Funds Market, Excess Reserves, and Unconventional Monetary Policy”, Journal of Economic Dynamics and Control, Vol. 53, pp. 225-250.

Hasan, I., Renzis, T. De and Schmiedel, H. (2013), "Retail Payments and the Real Economy”, European Central Bank Working Paper, No. 1572.

Hasan, I., Schmiedel, H. and Song, L. (2012), "Returns to Retail Banking and Payments", Journal of Financial Services Research, Vol. 41 No. 3, pp. 163-195.

Johnson, O.E.G. (1998), “The Payment System and Monetary Policy”, Paper on Policy Analysis and Assessment 
of the International Monetary Fund, Vol. PPAA/98/4.

Kahn, C.M. and Roberds, W. (2009), "Why Pay? An Introduction to Payments Economics”, Journal of Financial Intermediation, Vol. 18 No. 1, pp. 1-23.

Kamhi, N. (2006), "LVTS, the Overnight Market, and Monetary Policy”, Bank of Canada Working Papers, Vol. 06-15.

Korinek, A. (2010), "Regulating Capital Flows to Emerging Markets: An Externality View", University of Maryland.

Korinek, A. and Sandri, D. (2016), “Capital Controls or Macroprudential Regulation?”, Journal of International Economics, Vol. 99 No. Supplement 1, pp. S27-S42.

Kregel, J. (2009), "Why Don't the Bailouts Work? Design of a New Financial System versus a Return to Normalcy”, Cambridge Journal of Economics, Vol. 33 No. 4 SPEC. ISS., pp. 653-663.

Lippi, F. and Secchi, A. (2009), “Technological change and the households' demand for currency”, Journal of Monetary Economics, Vol. 56 No. 2, pp. 222-230.

MacKinnon, J.G., Haug, A.A. and Michelis, L. (1999), "Numerical Distribution Functions of Likelihood Ratio Tests for Cointegration”, Journal of Applied Econometrics, Vol. 14 No. 5, pp. 563-577.

Martowardojo, A.D.W. (2015), Inauguration of Indonesia Payment System Forum, available at: https://www.bis.org/review/r151009e.htm.

Merrouche, O. and Nier, E. (2009), "Payment Systems, Inside Money and Financial Intermediation”, Bank of England Working Paper, No. 371.

Merrouche, O. and Nier, E. (2012), “Payment Systems, Inside Money and Financial Intermediation”, Journal of Financial Intermediation, Vol. 21 No. 3, pp. 359-382.

Nguyen, V.H.T. and Boateng, A. (2013), “The Impact of Excess Reserves Beyond Precautionary Levels on Bank Lending Channels in China", Journal of International Financial Markets, Institutions and Money, Elsevier B.V., Vol. 26 No. 1, pp. 358-377.

Rinaldi, L. (2001), "Payment Cards and Money Demand in Belgium”, Center for Economic Studies Discussions Paper Series (DPS), No. 01.16.

Rockoff, H. (1993), “The Meaning of Money in the Great Depression”, NBER Historical Paper, No. 52.

Rousseau, P.L. and Wachtel, P. (2002), "Inflation thresholds and the finance - growth nexus", Journal of International Money and Finance, Vol. 21, pp. 777-793.

Snellman, H. and Viren, M. (2009), “ATM Networks and Cash Usage”, Applied Financial Economics, Vol. 19 No. 10, pp. 841-851.

Stix, H. (2003), "How Do Debit Cards Affect Cash Demand? Survey Data Evidence", Oesterreichische Nationalbank Working Paper, No. 82.

Titiheruw, I.S. and Atje, R. (2009), "Payment System in Indonesia: Recent Developments and Policy Issues", Asian Development Bank Institute Working Paper Series, No. 149.

Unsal, D.F. (2013), “Capital Flows and Financial Stability: Monetary Policy and Macroprudential Responses”, International Journal of Central Banking, Vol. 9 No. 1, pp. 233-285.

Wang, Z. and Wolman, A.L. (2016), "Payment Choice and Currency Use: Insights from Two Billion Retail Transactions", Journal of Monetary Economics, Elsevier, Vol. 84, pp. 94-115.

Warjiyo, P. (2014), "The Transmission Mechanism and Policy Responses to Global Monetary Developments: the Indonesian Experience”, BIS Papers, Vol. 78, pp. 199-216.

Yang, B.Z. and King, A.S. (2011), “Do Credit Cards Really Reduce Aggregate Money Holdings?”, Atlantic Economic Journal, Vol. 39 No. 1, pp. 85-95. 
Appendix A. List of Variables

\begin{tabular}{|c|c|c|}
\hline Variable & Description & Source \\
\hline $\begin{array}{l}\text { Excess Reserves Ratio } \\
\text { (ERDEP) }\end{array}$ & $\begin{array}{l}\text { The ratio of excess reserves held by private banks over total } \\
\text { deposits over total deposits }\end{array}$ & Bank Indonesia \\
\hline Currency ratio (CURSAV) & $\begin{array}{l}\text { The ratio of currency in circulation (outside the banking } \\
\text { system) over saving and demand deposits in the banking } \\
\text { sector }\end{array}$ & Bank Indonesia \\
\hline $\begin{array}{l}\text { Deviation of RTGS } \\
\text { Transaction from average } 1 \\
\text { year(DEV_RTGS) }\end{array}$ & $\begin{array}{l}\text { RTGS transactions value over moving average of RTGS } \\
\text { transactions in } 12 \text { months }\end{array}$ & Bank Indonesia \\
\hline $\begin{array}{l}\text { RTGS Limit } 1 \\
\text { (RTGSREG_02) }\end{array}$ & $\begin{array}{l}\text { Dummy for Nominal limit for Customer transfer in RTGS } \\
\text { system, } 0 \text { means no limit, } 1 \text { means there is limit }\end{array}$ & Bank Indonesia \\
\hline $\begin{array}{l}\text { RTGS Limit } 2 \\
\text { (RTGSREG_03) }\end{array}$ & $\begin{array}{l}\text { Dummy for Nominal limit for Customer transfer in RTGS } \\
\text { system, } 0 \text { means no limit, } 1 \text { means there is limit }\end{array}$ & Bank Indonesia \\
\hline $\begin{array}{l}\text { Deviation of Clearing } \\
\text { Transaction from average } 1 \\
\text { year (DEV_Clearing) }\end{array}$ & $\begin{array}{l}\text { Clearing transactions value over moving average of clearing } \\
\text { transactions in } 12 \text { months }\end{array}$ & Bank Indonesia \\
\hline Clearing Limit 1 & $\begin{array}{l}\text { Dummy for Nominal limit for credit transfer in clearing } \\
\text { system, } 0 \text { means no limit, } 1 \text { means there is limit }\end{array}$ & Bank Indonesia \\
\hline Clearing Limit 2 & $\begin{array}{l}\text { Dummy for Nominal limit for credit transfer in clearing } \\
\text { system, } 0 \text { means no limit, } 1 \text { means there is limit }\end{array}$ & Bank Indonesia \\
\hline $\begin{array}{l}\text { Number of ATM/Debit Card } \\
\text { transactions } \\
\text { (DEBVOLCARD) }\end{array}$ & $\begin{array}{l}\text { The number of debit cards transactions divided by number of } \\
\text { the number of debit cards in the economy }\end{array}$ & Bank Indonesia \\
\hline $\begin{array}{l}\text { Number of Credit Card } \\
\text { transactions } \\
\text { (DEBVOLCARD) }\end{array}$ & $\begin{array}{l}\text { The number of credit cards transactions divided by number } \\
\text { of the number of credit cards in the economy }\end{array}$ & Bank Indonesia \\
\hline $\begin{array}{l}\text { Total number of ATM/Debit } \\
\text { Card (ATMCARDPOP) }\end{array}$ & Total number of debit cards over 1000 population & Bank Indonesia \\
\hline $\begin{array}{l}\text { Total number of Credit } \\
\text { Card (CCCARDPOP) }\end{array}$ & Total number of credit cards over 1000 population & Bank Indonesia \\
\hline $\begin{array}{l}\text { Reserve requirement ratio } \\
\text { (RR) }\end{array}$ & $\begin{array}{l}\text { The ratio of Reserve Requirement for Commercial Banks } \\
\text { held at Bank Indonesia in Rupiah over total deposits }\end{array}$ & Bank Indonesia \\
\hline BI rate (BIRATE) & Bank Indonesia Policy Rate & Bank Indonesia \\
\hline Inflation (INF) & year-on-year CPI Inflation in Indonesia & $\begin{array}{l}\text { Statistics Indonesia } \\
\text { (BPS) }\end{array}$ \\
\hline Retail Sales (RET_SALES) & $\begin{array}{l}\text { Retail sales index based on the retail sales survey which is a } \\
\text { monthly survey to obtain prior information about the moving } \\
\text { trend of Gross Domestic Product by Private Consumption. } \\
\text { This survey is conducted by Bank Indonesia }\end{array}$ & Bank Indonesia \\
\hline Exchange Rate (XRATE) & the average monthly USD/IDR exchange rate & Bank Indonesia \\
\hline Loan & loan made by the banking sector & Bank Indonesia \\
\hline $\begin{array}{l}\text { Total ATM, EFTPOS } \\
\text { number (INFRA) }\end{array}$ & $\begin{array}{l}\text { Natural logarithm of total number of Automatic Teller } \\
\text { Machine and EFTPOS in Indonesia }\end{array}$ & $\begin{array}{l}\text { Bank Indonesia, } \\
\text { Financial Service } \\
\text { Authority (OJK) }\end{array}$ \\
\hline $\begin{array}{l}\text { Official Foreign Reserves } \\
\text { (FOREX) }\end{array}$ & The official foreign reserves in the central bank & Bank Indonesia \\
\hline $\begin{array}{l}\text { Holiday Dummy } \\
\text { (H_DUMMY) }\end{array}$ & Dummy to capture the Indonesian Holiday of Eid al-Fitr & \\
\hline
\end{tabular}


Appendix B. Descriptive Statistics

\begin{tabular}{|c|c|c|c|c|c|c|c|}
\hline Variables & Mean & Median & Maximum & Minimum & Std. Dev. & Skewness & Kurtosis \\
\hline ERDEP & 0.0255361 & 0.0240399 & 0.075440677 & 0.0019314 & 0.0119026 & 1.48170035 & 4.7441892 \\
\hline DEV_RTGS & 1.0675186 & 1.0400289 & 1.784332649 & 0.7511 & 0.1885868 & 0.904722966 & 0.9915821 \\
\hline DEV_CLEAR & 1.0670937 & 1.0458715 & 1.571035297 & 0.7187133 & 0.1369352 & 1.180998975 & 2.8885274 \\
\hline YSHOCK & 1.0056498 & 0.9905091 & 1.317623031 & 0.7759936 & 0.0881069 & 0.940404181 & 2.0066858 \\
\hline CURSAV & 0.2057814 & 0.2038749 & 0.274952828 & 0.1791246 & 0.0176916 & 0.916108093 & 1.2161389 \\
\hline ATM_VOLCARD & 3.1430727 & 3.1894669 & 3.873796295 & 2.3444615 & 0.318634 & -0.2955725 & -0.430924 \\
\hline RET_SALES & 119.3724 & 106.5 & 232.4 & 55.91 & 48.999157 & 0.568386811 & -0.990024 \\
\hline CPI & 95.117779 & 94.479434 & 129.72 & 58.403843 & 20.117734 & 0.028883581 & -1.073407 \\
\hline DEPO1M & 7.5702667 & 7.145 & 12.01 & 5.35 & 1.5770595 & 1.093341683 & 0.8358835 \\
\hline ATMCARDPOP & 272.08856 & 231.39148 & 574.0163661 & 112.8822 & 134.27069 & 0.604893676 & -0.906009 \\
\hline INFRA & 2.1494258 & 0.1411513 & 7.882031658 & 0.0631363 & 2.9016321 & 0.852445471 & -1.069247 \\
\hline CCVOLCARD & 1.3183943 & 1.2993122 & 1.652340979 & 1.0212316 & 0.1186498 & 0.356451979 & 0.1467754 \\
\hline CCCARDPOP & 52.600319 & 57.726263 & 68.27055913 & 25.216054 & 12.121138 & -0.700423572 & -0.729577 \\
\hline LOANGROWTH & 0.1749987 & 0.1918965 & 0.331209442 & 0.055698 & 0.067931 & 0.021442625 & -0.9878 \\
\hline SALESG & 0.0993405 & 0.1023685 & 0.338975367 & -0.305203 & 0.1080364 & -1.005271013 & 3.0905041 \\
\hline INF & 0.0655709 & 0.0608774 & 0.168741961 & 0.0238571 & 0.0321818 & 1.444167087 & 1.9333098 \\
\hline BIRATE & 0.0762293 & 0.0747 & 0.1275 & 0.0575 & 0.0175417 & 1.469715907 & 1.8868199 \\
\hline XRATE & 10507.033 & 9610 & 14657 & 8508 & 1723.4661 & 0.778707691 & -0.924868 \\
\hline $\mathbf{R R}$ & 0.0684 & 0.075 & 0.08 & 0.05 & 0.0130605 & -0.545248396 & -1.505474 \\
\hline
\end{tabular}


Appendix C. Customers' Transaction Limit in Indonesian Large Value Payment Systems

\begin{tabular}{|c|c|c|c|c|}
\hline Reg No & Date & Title & Clearing Limit & RTGS Limit \\
\hline 4/12/DASP & 24-Sep-02 & $\begin{array}{l}\text { Clearing Schedule and Final Settlement Date of } \\
\text { the Local Clearing System and Nominal limit of a } \\
\text { Note }\end{array}$ & $\begin{array}{l}\text { - max Rp100,000,000.00 } \\
\text { for credit transfer }\end{array}$ & \\
\hline 6/45/DASP & 25-Oct-04 & Nominal limit for Customer transfer for RTGS & & $\begin{array}{l}\text { Min Rp25,000,000.00 for } \\
\text { following dates: } \\
\text { - 8-22 Nov } 2004 \\
\text {-20-31 Dec } 2004\end{array}$ \\
\hline 7/43/DASP & 7-Sep-05 & $\begin{array}{l}\text { Nominal Limit for debit note and credit transfer in } \\
\text { clearing }\end{array}$ & $\begin{array}{l}\text { - max Rp10,000,000,00 } \\
\text { for debit note } \\
\text { - Max } \\
\text { Rp100,000,000.00 for } \\
\text { credit transfer }\end{array}$ & \\
\hline 7/47/DASP & $13-O c t-05$ & Nominal limit for Customer transfer for RTGS & & $\begin{array}{l}\text { Min Rp25,000,000.00 for } \\
\text { following dates: } \\
\text { - } 24 \text { Oct-9 Nov } 2005 \\
\text { - } 19-30 \text { Dec } 2005\end{array}$ \\
\hline 11/13/DASP & 4-May-09 & $\begin{array}{l}\text { Nominal value limit of a Debit Note and Credit } \\
\text { Transfer }\end{array}$ & $\begin{array}{l}\text { - max Rp10,000,000,00 } \\
\text { for debit note } \\
\text { - Max } \\
\text { Rp100,000,000.00 for } \\
\text { credit transfer }\end{array}$ & \\
\hline 15/18/DASP & 30-Apr-13 & $\begin{array}{l}\text { Amendment of Nominal value limit of a Debit } \\
\text { Note and Credit Transfer }\end{array}$ & $\begin{array}{l}\text { - Max Rp500.000.000 } \\
\text { for credit transfer started } \\
\text { from } 31 \text { May } 2013\end{array}$ & \\
\hline 16/18/DPSP & 28-Nov-14 & Amendment of RTGS System & & $\begin{array}{l}\text { Min Rp100,000,000.00 for } \\
\text { Customer transfer }\end{array}$ \\
\hline 17/35/DPSP & $13-$ Nov-15 & $\begin{array}{l}\text { Nominal value limit for fund transfer through } \\
\text { RTGS and Clearing }\end{array}$ & $\begin{array}{l}-16 \text { Nov 2015-30 Jun } \\
2016 \text {-> no limit } \\
\text { - } 1 \text { Jul } 2016 \text {-> max } \\
\text { Rp500,000,000.00 per } \\
\text { transaction }\end{array}$ & $\begin{array}{l}\text { - } 16 \text { Nov 2015-30 Jun 2016: } \\
\text { min Rp500,000,000.00 per } \\
\text { transaction } \\
\text { - 1 Jul 2016 -> min } \\
\text { Rp100,000,000.00 per } \\
\text { transaction }\end{array}$ \\
\hline 18/7/DPSP & 2-May-16 & Fund Transfer and Scheduled Clearing & Debit note unlimited & \\
\hline 18/40/DPSP & 30-Dec-16 & $\begin{array}{l}\text { Amendment of Fund Transfer and Scheduled } \\
\text { Clearing }\end{array}$ & $\begin{array}{l}\text { Debit note max } \\
\text { Rp500,000,000.00 per } \\
\text { transaction }\end{array}$ & \\
\hline
\end{tabular}




\section{Appendix D. Lag Order Selection Criteria Test}

VAR Lag Order Selection Criteria

\begin{tabular}{|c|c|c|c|c|c|c|}
\hline \multicolumn{7}{|c|}{$\begin{array}{l}\text { Endogenous variables: CURSAV DEB } \\
\text { Exogenous variables: C H_DUMMY }\end{array}$} \\
\hline Lag & LogL & LR & FPE & AIC & SC & HQ \\
\hline 0 & 626.1704 & NA & $4.25 \mathrm{E}-13$ & -8.622119 & -8.330699 & -8.503697 \\
\hline 1 & 1803.992 & 2206.343 & $5.29 \mathrm{E}-20$ & -24.52102 & $-23.20963^{*}$ & -23.98812 \\
\hline 2 & 1904.372 & 178.139 & $2.58 \mathrm{E}-20$ & -25.24468 & -22.91332 & $-24.29731 *$ \\
\hline 3 & 1958.437 & $90.61501 *$ & $2.44 \mathrm{e}-20 *$ & $-25.31601 *$ & -21.96468 & -23.95417 \\
\hline 4 & 1998.091 & 62.55251 & $2.85 \mathrm{E}-20$ & -25.18437 & -20.81308 & -23.40806 \\
\hline 5 & 2030.497 & 47.92575 & $3.75 \mathrm{E}-20$ & -24.95067 & -19.55941 & -22.75988 \\
\hline 6 & 2066.405 & 49.56187 & $4.80 \mathrm{E}-20$ & -24.76626 & -18.35503 & -22.161 \\
\hline 7 & 2109.241 & 54.90254 & $5.71 \mathrm{E}-20$ & -24.67944 & -17.24825 & -21.65971 \\
\hline 8 & 2149.393 & 47.50432 & $7.29 \mathrm{E}-20$ & -24.55483 & -16.10366 & -21.12062 \\
\hline \multicolumn{7}{|c|}{ * indicates lag order selected by the criterion } \\
\hline \multicolumn{7}{|c|}{ LR: sequential modified LR test statistic (each test at $5 \%$ level) } \\
\hline \multicolumn{7}{|c|}{ FPE: Final prediction error } \\
\hline \multicolumn{7}{|c|}{ AIC: Akaike information criterion } \\
\hline \multicolumn{7}{|c|}{ SC: Schwarz information criterion } \\
\hline \multicolumn{7}{|c|}{ HQ: Hannan-Quinn information criterion } \\
\hline
\end{tabular}

\section{VAR Lag Order Selection Criteria}

Endogenous variables: CURSAV CCVOLCARD Y INF DEPO1M CCCARDPOP INFRA Exogenous variables: C H_DUMMY

\begin{tabular}{r|r|r|r|r|r|r|}
\hline Lag & LogL & LR & FPE & \multicolumn{1}{c|}{ AIC } & \multicolumn{1}{c|}{ SC } & \multicolumn{1}{c|}{ HQ } \\
\hline 0 & 698.9899 & NA & $1.52 \mathrm{E}-13$ & -9.647745 & -9.356325 & -9.529324 \\
\hline 1 & 1758.247 & 1984.242 & $1.01 \mathrm{E}-19$ & -23.87672 & -22.56533 & -23.34383 \\
\hline 2 & 1887.541 & 229.4503 & $3.27 \mathrm{E}-20$ & -25.00761 & $-22.67626^{*}$ & $-24.06024^{*}$ \\
\hline 3 & 1938.968 & 86.19586 & $3.21 \mathrm{E}-20$ & -25.04181 & -21.69048 & -23.67996 \\
\hline 4 & 1994.434 & 87.49515 & $3.00 \mathrm{e}-20 *$ & -25.13287 & -20.76158 & -23.35656 \\
\hline 5 & 2032.326 & 56.0376 & $3.66 \mathrm{E}-20$ & -24.97642 & -19.58516 & -22.78563 \\
\hline 6 & 2088.398 & 77.39498 & $3.52 \mathrm{E}-20$ & -25.07603 & -18.6648 & -22.47076 \\
\hline 7 & 2141.734 & $68.36056^{*}$ & $3.61 \mathrm{E}-20$ & $-25.13710^{*}$ & -17.7059 & -22.11736 \\
\hline 8 & 2189.761 & 56.81985 & $4.13 \mathrm{E}-20$ & -25.12339 & -16.67222 & -21.68918 \\
\hline
\end{tabular}

* indicates lag order selected by the criterion

LR: sequential modified LR test statistic (each test at 5\% level)

FPE: Final prediction error

AIC: Akaike information criterion

SC: Schwarz information criterion

HQ: Hannan-Quinn information criterion 


\section{Appendix E. Robustness Test}

Endogeneity Test

Null hypothesis: DEV_RTGS are exogenous

Specification: ERDEP C DEV_RTGS RR IBRATE YSHOCK ERDEP(-1) RTGSREG_02 RTGSREG_03 H_DUMMY

Instrument specification: C DEV_RTGS(-1) DEV_RTGS(-2) RR IBRATE YSHOCK ERDEP(-1) ERDEP(-2) RTGSREG_02 RTGSREG_03 H_DUMMY

Endogenous variables to treat as exogenous: DEV_RTGS

\begin{tabular}{|lccr|}
\hline & Value & df & Probability \\
Difference in J-stats & 3.051261 & 1 & 0.0807 \\
& & & \\
J-statistic summary: & & & \\
& Value & & \\
Restricted J-statistic & 12.17313 & 9.121868 & \\
Unrestricted J-statistic & & & \\
\hline
\end{tabular}

\section{Endogeneity Test}

\begin{tabular}{|c|c|c|c|}
\hline \multicolumn{4}{|c|}{ Null hypothesis: DEV_CLEAR are exogenous } \\
\hline \multicolumn{4}{|c|}{$\begin{array}{l}\text { Specification: ERDEP C DEV_CLEAR RR IBRATE YSHOCK ERDEP(-1) CLEARREG_01 } \\
\text { CLEARREG_02 H_DUMMY }\end{array}$} \\
\hline \multicolumn{4}{|c|}{$\begin{array}{l}\text { Instrument specification: C DEV_CLEAR(-1) DEV_CLEAR(-2) RR IBRATE YSHOCK ERDEP(-1) } \\
\text { ERDEP(-2) CLEARREG_01 CLEARREG_02 H_DUMMY }\end{array}$} \\
\hline \multicolumn{4}{|c|}{ Endogenous variables to treat as exogenous: DEV_CLEAR } \\
\hline & Value & $\mathrm{df}$ & Probability \\
\hline Difference in J-stats & 0.241072 & 1 & 0.6234 \\
\hline \multicolumn{4}{|l|}{ J-statistic summary: } \\
\hline & Value & & \\
\hline Restricted J-statistic & 9.098977 & & \\
\hline Unrestricted J-statistic & 8.857905 & & \\
\hline
\end{tabular}

Heteroskedasticity and Serial Correlation Test for CURSAV DEB_VOLCARD Y INF DEPO1M DEBCARDPOP INFRA

\begin{tabular}{|l|r|l|r|}
\hline \multicolumn{1}{|c|}{ Test } & Test Stat & & P value \\
\hline $\begin{array}{l}\text { Heteroskedasticity: } \\
\text { White test }\end{array}$ & 1603.927 & Prob. Chi-Square(1652) & 0.7976 \\
Chi-sq & & Probs from chi-square & \\
\hline VEC Residual Serial & with 49 df. & 0.4274 \\
Correlation LM Tests & 50.15354 & & 0.7448 \\
Lags: 1 & 42.15553 & & 0.1834 \\
2 & 57.74944 & & 0.7225 \\
3 & 42.767 & & \\
4 & & & \\
\hline
\end{tabular}


Heteroskedasticity and Serial Correlation Test for CURSAV DEB_VOLCARD Y INF DEPO1M DEBCARDPOP INFRA

\begin{tabular}{|l|r|l|r|}
\hline \multicolumn{1}{|c|}{ Test } & Test Stat & & \multicolumn{2}{c|}{ P value } \\
\hline $\begin{array}{l}\text { Heteroskedasticity: } \\
\text { White test } \\
\text { Chi-sq }\end{array}$ & 2397.211 & Prob. Chi-Square(2436) & \\
& & & 0.7085 \\
\hline VEC Residual Serial & & Probs from chi-square & \\
Correlation LM Tests & with 49 df. & \\
Lags: 1 & 50.35882 & & 0.4195 \\
2 & 65.12036 & & 0.0613 \\
3 & 65.76833 & & 0.0551 \\
4 & 56.31361 & & 0.2202 \\
5 & 53.40957 & & 0.3087 \\
6 & 56.49819 & & 0.2152 \\
7 & 55.64499 & & 0.2389 \\
\hline
\end{tabular}

\section{Endogeneity Test}

Null hypothesis: CURSAV are exogenous

Specification: LOANGROWTH C CURSAV YG INF BIRATE XRATE RR LOANGROWTH(-1)

Instrument specification: C C CURSAV(-1) CURSAV(-2) CURSAV(-3) CURSAV(-4) YG YG(-1) YG(-2)

YG(-3) YG(-4) INF INF(-1) INF(-2) INF(-3) INF(-4) BIRATE BIRATE(-1) BIRATE(-2) BIRATE(-3)

BIRATE(-4) LOANGROWTH(-1) LOANGROWTH(-2) LOANGROWTH(-3) LOANGROWTH(-4)

XRATE XRATE(-1) XRATE(-2) XRATE(-3) XRATE(-4) RR RR(-1) RR(-2) RR(-3) RR(-4) H_DUMMY

Endogenous variables to treat as exogenous: CURSAV

\begin{tabular}{|lccc|}
\hline & Value & df & Probability \\
Difference in J-stats & 5.838016 & 1 & 0.0157 \\
J-statistic summary: & & & \\
& Value & & \\
Restricted J-statistic & 72.93654 & & \\
Unrestricted J-statistic & 67.09852 & & \\
\hline
\end{tabular}

Endogeneity Test

Null hypothesis: ERDEP are exogenous

Specification: LOANGROWTH C ERDEP SALESG INF BIRATE XRATE RR LOANGROWTH(-1) Instrument specification: C ERDEP(-1) ERDEP(-2) ERDEP(-3) ERDEP(-4) YG YG(-1) YG(-2) YG(-3)

YG(-4) INF INF(-1) INF(-2) INF(-3) INF(-4) BIRATE BIRATE(-1) BIRATE(-2) BIRATE(-3) BIRATE(-4) LOANGROWTH(-1) LOANGROWTH(-2) LOANGROWTH(-3) LOANGROWTH(-4) XRATE XRATE(-1) XRATE(-2) XRATE(-3) -3) LOANGROWTH(-4) XRATE XRATE(-1) XRATE(-2) XRATE(-3) XRATE(-4) RR RR(-1) RR(-2) RR(-3) RR(-4) H_DUMMY

Endogenous variables to treat as exogenous: ERDEP

\begin{tabular}{|lccr|}
\hline & Value & df & Probability \\
Difference in J-stats & 0.203625 & 1 & 0.6518 \\
J-statistic summary: & & & \\
& Value & & \\
Restricted J-statistic & 75.83774 & & \\
Unrestricted J-statistic & 75.63412 & & \\
\hline
\end{tabular}




\section{Appendix F Selected Impulse Response of Variable CURSAV}
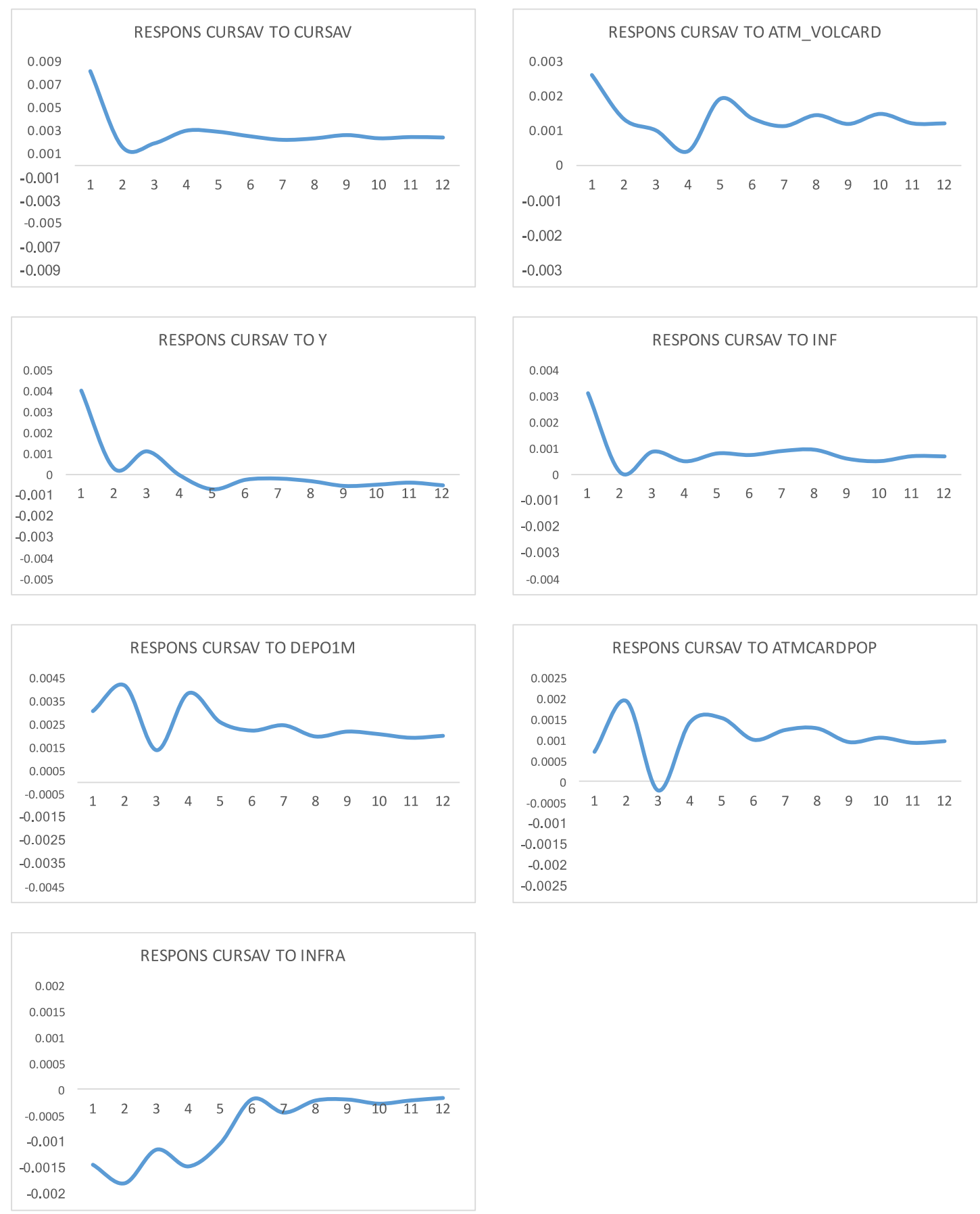

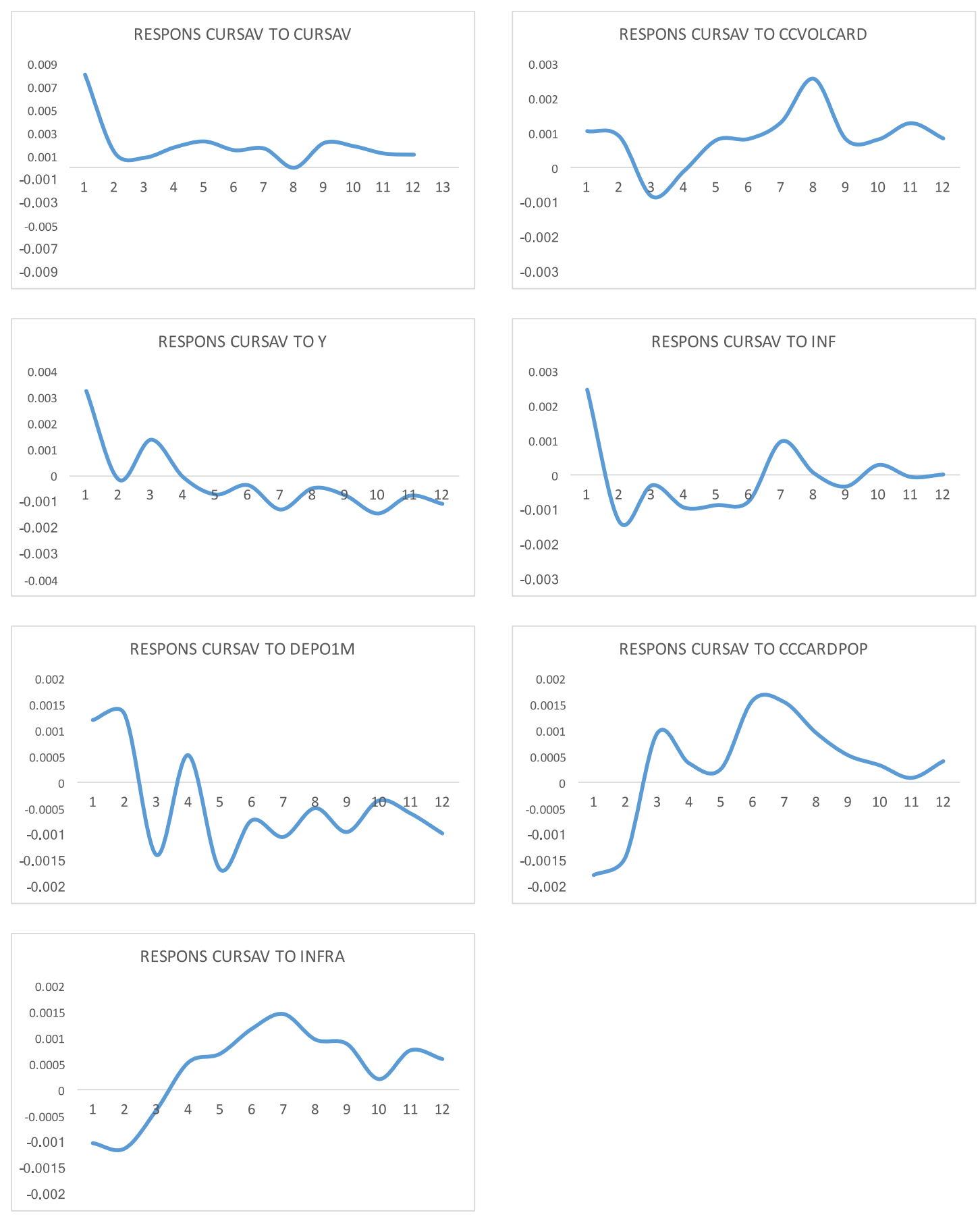